\title{
Which Cases Go to Trial: An Empirical Study of Predictors of Failure to Settle?
}

Leandra Lederman

Follow this and additional works at: https://scholarlycommons.law.case.edu/caselrev

Part of the Law Commons

\section{Recommended Citation}

Leandra Lederman, Which Cases Go to Trial: An Empirical Study of Predictors of Failure to Settle ?, 49 Case W. Rsrv. L. Rev. 315 (1999)

Available at: https://scholarlycommons.law.case.edu/caselrev/vol49/iss2/4

This Article is brought to you for free and open access by the Student Journals at Case Western Reserve University School of Law Scholarly Commons. It has been accepted for inclusion in Case Western Reserve Law Review by an authorized administrator of Case Western Reserve University School of Law Scholarly Commons. 


\title{
WHICH CASES Go TO TRIAL?: AN EMPIRICAL STUDY OF PREDICTORS OF FAILURE TO SETTLE
}

\author{
Leandra Lederman ${ }^{\dagger}$
}

TABLE OF CONTENTS

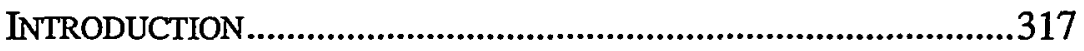

I. THE LIMITS OF CASE-SELECTION THEORY .................................318

A. The Basic Model of Suit and Settlement ...............................319

B. The Predictions of Case-Selection Models ..........................321

C. Difficulties in Testing the Models.........................................324

II. Which CaSEs Go to TRIAL?: THE Study OF

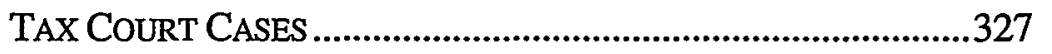

$\dagger \quad$ Associate Professor, George Mason University School of Law. A.B. 1987, Bryn Mawr College; J.D. 1990, New York University School of Law; LL.M. 1993, New York University School of Law. This study could not have been done without the assistance of many people. Above all, special thanks are due to Lisa Bernstein, Bruce Kobayashi and Sally Lederman. I am also grateful to Lloyd Cohen, David Hyman, Steve Johnson, Hal Lewis, Mark Newton, Dave Oedel, Erin O'Hara, Maureen O'Rourke, Kent Syverud and workshop participants at George Mason Law School, Maryland Law School and Mercer Law School for helpful comments on earlier versions of this Article. Mercer law students Suzanne Causey, Jason Long, John McCown, Ernest Sellers and Jeanne Strickland provided indispensable research assistance and assistance in off-site data collection. George Mason law student Sam Taylor also provided valuable research assistance. Deborah Healy provided invaluable assistance in collecting data from files of the United States Tax Court (Tax Court). I am very grateful to Dr. Scott Clark, of Emory University School of Public Health, for his excellent statistical work, and to the following people who provided statistical support during various phases of the project: George Cotsonis of Emory University, Howard Lasus of George Mason University, Chandler Pike of Mercer University and Dr. Jack Reeves of the University of Georgia. Hope Ince and Elizabeth Freeney did excellent data entry work. I would also like to thank Charles S. Casazza, Clerk of the Tax Court, who provided some general statistical information and access to public files; Hazel Keahy of the Clerk's Office of the Tax Court, and Ruth Miles, the head of the Public Files Office of the Tax Court. I am also grateful to Mercer Law School and the Law and Economics Center of George Mason University for financial support. 
III. STUDY RESULTS AND IMPLICATIONS FOR CASE-SELECTION MODELS.

A. The Study Results and Insights into the Models .332 B. Generalizability of the Results to Other Civil Litigation ....341 CONCLUSION. .343 Appendix A ...... .345 Appendix $B$ .348 Appendix $C$ .351 Appendix D. .353 Appendix $E$ .357 Appendix $F$ .358 


\section{INTRODUCTION}

Many scholars have theorized that cases that go to trial are not representative of the larger pool of disputes. 'If tried cases are substantively different from the much larger set of cases that settle prior to trial, ${ }^{2}$ then published case law provides only a distorted window into peoples' behavior in response to legal rules, ${ }^{3}$ unless we determine the mechanisms by which cases are "selected" for trial.

Although most scholars agree that litigated cases are an unrepresentative sample of legal disputes, they disagree on what causes trials, ${ }^{4}$ and little empirical evidence exists about what factors impact on

${ }^{1}$ One of the most well-known theories that cases nonrandomly go to trial or settle is developed in Priest and Klein's landmark article. See George L. Priest \& Benjamin Klein, The Selection of Disputes for Litigation, 13 J. LEGAL STUD. 1, 3 (1984) (demonstrating that, under certain assumptions, cases closest to the applicable "decision standard" are disproportionately selected for trial); see also Theodore Eisenberg, Litigation Models and Trial Outcomes in Civil Rights and Prisoner Cases, 77 GEO. L.J. 1567, 1568 (1989) (stating that "expectations theory" suggests that cases that go to trial might not reflect the characteristics of the pool of all disputes). Other theories also predict that cases are not randomly tried or settled, although the theories disagree about which cases are more likely to be selected for trial. See infra notes 2335 and accompanying text.

${ }^{2}$ Most cases settle. See, e.g., Janet Cooper Alexander, Do the Merits Matter? A Study of Settlements in Securities Class Actions, 43 STAN. L. REV. 497, 498 (1991) (stating that five percent or less of litigated cases are tried to judgment) (citing Annual Report of the Director, Administrative Office of United States Courts, in 1987 REPORTS OF THE PROCEEDINGS OF THE JUDICIAL CONFERENCE OF THE UNITED STATES 211 tbl. C4A); Judith Resnik, Managerial Judges, 96 HARV. L. REV. 374, 405 (1982) ("Eighty-five to ninety percent of all federal civil suits end by settlement.") (footnote omitted); David M. Trubek et. al., The Costs of Ordinary Litigation, 31 UCLA L. REV. 72,89 (1983) (stating that approximately $8 \%$ of civil suits filed in state or federal court went to trial).

Settlement figures are similar for tax cases. See, e.g., James A. McQueen, Tax Litigation and Attomey's Fees: Still a Win-Lose Dichotomy, 57 S. CAL. L. REV. 471, 473 (1984) ("[N]inety-seven percent of all tax disputes with the IRS are resolved without recourse to trial."). Internal Revenue Service (IRS) data reflects that from 1990 through 1994, approximately $74.0 \%$ to $80.1 \%$ of regular cases filed in Tax Court settled and only $5.0 \%$ to $5.5 \%$ of the cases resulted in a trial and opinion decision. See IRS data sent to author after a FOIA request (on file with author).

3 See, e.g., Orley Ashenfelter et al., Politics and the Judiciary: The Influence of Judicial Background on Case Outcomes, 24 J. LEGAL STUD. 257, 259 (1995) (stating that bias in the selection of disputes for trial presents problems in evaluating whether judicial ideology affects case outcomes); Theodore Eisenberg, The Relationship Between Plaintiff Success Rates Before Trial and at Trial, 154 J.R. STAT. SoC. 111, 111 (1991) ("For example, if tried cases contain equal victories for plaintiffs and defendants, one cannot conclude that the applicable legal rules are even-handed. Even if the rules heavily favour the plaintiff, the similar trial success rates are consistent with there being many cases in which plaintiffs recover without going to trial."); Robert H. Gertner, Asymmetric Information, Uncertainty, and Selection Bias in Litigation, 1993 U. CHI. L. SCH. ROUNDTABLE 75, 76 ("Understanding the process by which disputes settle or fail to settle will help legal scholars unravel the biases created by the selection effect. They might then 'adjust' the data on litigated cases taking the selection bias for the settlement process into account, and thus learn more from the existing data."); Priest \& Klein, supra note 1, at 3 (stating that Posner's inference of efficiency of nineteenth century negligence law based on a large sample of appellate cases requires the presumption that no cases involving alternative liability standards were settled prior to appeal); Peter Siegelman \& John J. Donohue III, The Selection of Employment Disputes for Litigation: Using Business Cycle Effects to Test the Priest-Klein Hypothesis, 24 J. LEGAL STUD 427, 429 (1995) ("If cases are not randomly selected for litigation, then a researcher who uses litigated cases is necessarily studying both the selection mechanism and the underlying population of cases simultaneously.").

${ }^{4} \mathrm{As}$ a result, the formal models of suit and settlement variously predict that the cases selected for trial will disproportionately be the "close" cases, the clear cases or the cases favoring repeat litigants. See infra notes $23-35$ and accompanying text. 
a case's likelihood of going to trial. ${ }^{5}$ In fact, the validity of empirical tests of the formal models of suit and settlement has been limited by the strong assumptions behind the models, assumptions that generally do not hold true in actual cases. ${ }^{6}$

This Article seeks to determine whether trials are nonrandom, and, if they are not, which factors predict that a case will go to trial. Unlike most other studies, this Article does not resort to limiting assumptions, because the data set, docketed Tax Court cases, contains settled cases that can be directly compared to the cases in the sample that went to trial. ${ }^{7}$ After finding that trials are nonrandom, the Article examines the case features that predict trials, and then seeks to make inferences from the statistical results about the applicability of theoretical models of suit and settlement to actual cases. To make those inferences, the Article also considers to what extent the Tax Court results are analogous to other types of civil litigation.

Part I of the Article analyzes why many scholars believe that suits are not randomly selected for trial, and why prior empirical studies have not definitively confirmed that hypothesis. Part II discusses my empirical study, the focus of this Article, which found that docketed Tax Court cases did not settle or go to trial randomly. In order to gain insights into suit and settlement models, Part III builds on the study's results, namely, that case characteristics such as predocketing administrative dispute resolution, higher stakes in the case and certain characteristics of the judge to which the case is assigned, increase the likelihood that a case will go to trial. This Part examines both the key elements of the theories and the study results in light of the theories, and also analyzes the generalizability of this study outside the Tax Court context.

\section{THE LIMITS OF CASE-SELECTION THEORY}

Resolution of a legal dispute is a multi-stage process following an underlying event and consists of the injured party's deciding whether to assert a legal claim, ${ }^{8}$ the bargaining process after the claim

\footnotetext{
${ }^{5}$ See Robert D. Cooter \& Daniel L. Rubinfeld, Economic Analysis of Legal Disputes and Their Resolution, 27 J. ECON. LITERATURE 1067, 1069 (1989) (noting that empirical research on the economics of legal disputes lags behind theoretical advances).

${ }^{6}$ The models generally assume disputes only over damages, not liability; that parties are risk-neutral; that they form accurate and unbiased estimates of the likely outcome at trial; that they have equal stakes in the outcome; and/or that they do not engage in strategic behavior. See infra notes 18-21 and accompanying text.

7 The Tax Court is an excellent laboratory for a study of this kind because the stakes are generally established from the outset (no punitive damages can be awarded); the trials are bench trials, so there is no need to control for collective decision-making by juries; and the Tax Court keeps records of settled cases. See infra text accompanying note 46.

${ }^{8}$ See generally Steven Shavell, Alternative Dispute Resolution: An Economic Analysis, 24 J. LEGAL STUD. 1 (1995) (examining reasons why parties would choose alternative dispute resolution $(\mathrm{ADR})$ as opposed to trial).
} 
is asserted but before trial, and finally, trial. ${ }^{9}$ A dispute can be resolved at any time in the process; analyzing only court decisions therefore ignores the disputes that dropped out along the way. And, in fact, most disputes do drop out before trial; as noted, the vast majority of cases settle. ${ }^{10}$ Although some trials are necessary, at least to establish precedent that assists in settling other cases, ${ }^{11}$ trials are so relatively rare that they are sometimes viewed as "failures" of the system.

\section{A. The Basic Model of Suit and Settlement}

From an economic perspective, it is understandable why the vast majority of cases settle. The alternative to settlement is litigation, ${ }^{13}$ which is generally more expensive. By settling, the parties create a "surplus" (the aggregate of the amounts each would have spent to go to trial) that they can divide between them. ${ }^{14}$ Professor Steven Shavell uses the following example: $:^{15}$

${ }^{9}$ See Cooter \& Rubinfeld, supra note 5, at 1069 (describing the chronology of a typical legal dispute); see also Jeffrey M. Perloff \& Daniel L. Rubinfeld, Settlements in Private Antitrust Litigation, in PRIVATE ANTITRUST LITIGATION 149 (Lawrence J. White ed., 1988) ("Litigation consists of three interdependent strands: first, the decision by the plaintiff whether to file suit; second, the decisions by plaintiff and defendant whether to settle; and third, the decisions by both parties as to what type of effort to put forth during the trial."). Appeal of the trial court's decision is another possible step in the process.

${ }_{11}^{10}$ See supra note 2.

11 That is, parties are said to "bargain in the shadow of the law"; they factor legal rules into the trial expectations that drive settlements. Russell Korobkin \& Chris Guthrie, Psychological Barriers to Litigation Settlement: An Experimental Approach, 93 MICH. L. REV. 107, 117 (1994) (quoting Robert $H$. Mnookin \& Lewis Komhauser, Bargaining in the Shadow of the Law: The Case of Divorce, 88 YALE L.J. 950 (1979)); see also Alexander, supra note 2, at 501-02 (discussing the economic model theory that "settlement decisions are made by comparing the economic value of the offer to the economic value of going to trial'); Patrick E. Longan, Congress, the Courts, and the Long Range Plan, 46 AM. U. L. REV. 625, 662 (1997) ("Without question, the government should subsidize litigation to some extent because private litigants create precedent that enables other litigants to resolve or avoid disputes; thus, that precedent has public value.").

${ }^{12}$ See, e.g., Samuel R. Gross \& Kent D. Syverud, Don't Try: Civil Jury Verdicts in a System Geared to Settlement, 44 UCLA L. REV. 1, 49 (1996) [hereinafter, Gross \& Syverud, Don't Try] ("The fact that trials usually are expensive winner-take-all affairs reinforces the consensus that they are dangerous and to be shunned."); Samuel R. Gross \& Kent D. Syverud, Getting to No: A Study of Settlement Negotiations and the Selection of Cases for Trial, $90 \mathrm{MICH}$. L. REV. 319, 320 (1991) [hereinafter Gross \& Syverud, Getting to No] ("A trial is a failure.").

${ }^{13}$ Settlement is inherently tied to litigation; that is particularly true of cases in which suit has been filed. See Alexander, supra note 2 , at 500 .

${ }_{14}$ See Bruce L. Hay, Effort, Information, Settlement, Trial, 24 J. LEGAL STUD. 29, 29 (1995) (noting that settling saves litigation costs, so parties can divide surplus created by not litigating); James D. Miller, Using Lotteries to Expand the Range of Litigation Settlements, $26 \mathrm{~J}$. LEGAL STUD. 69, 69 (1997) ("Litigating parties incur deadweight losses that they could avoid if they settled their case."); Shavell, supra note 8 , at 11 ("[T]he difference between the plaintiffs expected judgment and the defendant's expected judgment must exceed the sum of their trial costs for there to be a trial; otherwise they will settle to save trial costs. This makes sense, in that the two parties together will save the sum of their trial costs if they settle.") (footnote omitted).

${ }^{15}$ This example is based on the standard model of litigation, which provides that, in considering an acceptable settlement amount, each side in the lawsuit determines the amount of the expected judgment if plaintiff were to win at trial, discounted by the likelihood of plaintiff victory, taking into account the costs of litigation and settlement. See Alexander, supra note 2, at 501-02. The parties base the expected judgment on precedent and other legal rules. See id. at 503. This should be true in tax cases, as well. See Andrea K. Feirstein, Note, Smith v. Commis- 
[Assume that] [t]he plaintiff believes he will win $\$ 10,000$ with likelihood 70 percent, and his trial costs would be $\$ 1,000$. Thus, he would gain $\$ 7,000-\$ 1,000=\$ 6,000$ from trial, so he would accept any amount greater than this in settlement. If the defendant believes the plaintiff's chances of winning at trial are the same and would face trial costs of $\$ 2,000$, the defendant's expected losses would be $\$ 7,000+\$ 2,000=\$ 9,000$. Hence, the plaintiff's minimum acceptable amount, $\$ 6,000$, is below the defendant's maximum acceptable amount, $\$ 9,000$, so there would be a settlement. The reason that there is a range for settlement is that each side would have to pay trial costs; the plaintiff subtracts these from his expected judgment to see what he would net, and the defendant adds them to his expected judgment to see the total he would have to pay. Hence, the sum of trial costs, $\$ 3,000$, is what separates the plaintiff's minimum acceptable settlement amount from the defendant's maximum acceptable amount. ${ }^{16}$

At first blush, the example suggests that it is surprising that any cases go to trial, given the economic advantages to the parties from

sioner: Unilateral Concessions by Taxpayers, 4 VA. TAX REV. 187, 206 (1984) ("It is generally assumed that a taxpayer concedes his liability only after careful calculation of several factors. A taxpayer will multiply the full liability by an estimated probable outcome to determine the expected savings to her in proceeding to trial. In determining whether to concede, a taxpayer adds the cost of concession to the amount of expected savings. This total is then compared to the taxpayer's probable litigation costs to be incurred if the case is tried. If the former total is less than or equal to the latter, the taxpayer should concede.") (citation omitted).

${ }^{16}$ See Shavell, supra note 8, at 11 . This example assumes a risk-neutral plaintiff and defendant. See id. at 10 n.16 ("I maintain the assumption of risk neutrality for simplicity in this and the next two subsections."). "Risk neutrality" means that a party is indifferent between a guaranteed amount, such as the $\$ 7,000$ settlement in the example, and its equivalent expected value, such as the $70 \%$ probability of a $\$ 10,000$ award at trial (assuming for the moment that litigation costs are zero). See Perloff \& Rubinfeld, supra note 9, at 152 ("Risk neutral individuals or firms make decisions solely on the basis of the expected return associated with their actions .... They are willing to take a 'fair' bet ...."). Risk aversion would increase the likelihood of settlement because a risk-averse party will pay more (or accept less) for a sure outcome than an uncertain one. Risk-seeking behavior creates the opposite dynamic.

The example also assumes that settlement costs are zero. See Shavell, supra note 8, at 10 ("Trial is assumed to involve a cost for each side, but, for simplicity, suit is taken to be costless."). However, the example can easily be adapted to reflect positive settlement costs, and the same result will still hold so long as the costs of litigating through trial are more than the costs of settling prior to trial. In other words, another way to think about this example is that the difference in costs incurred in settling prior to trial and going to trial is $\$ 3,000$.

The economic approach to suit versus settlement should be essentially the same in Tax Court as in other litigation. See Carlton M. Smith, Innovative Settlement Techniques Can Reduce Litigation Costs, 8 J. TAX'N 76, 80 (1993) ("IIn a Tax Court chambers conference, the] judge also may ask the parties if they would be interested in hearing the judge's tentative views on how he or she would rule in the case, assuming the parties presented the evidence they said they would present. The judge sometimes will give his or her views as a percentage, as in: 'I think there is a $60 \%$ chance I will rule for the petitioner on this issue.' Giving views in this way often lends to quick settlements on the stated percentage basis."); see also Alan J. Reyner, Representing a Client Before the IRS, 3 S.C. LAW., July-Aug. 1991, at 18, 21 ("In Tax Court,] District Counsel will attempt to settle the case before trial and will look at all evidence as well as at the hazards of litigation."); infra note 60 and accompanying text (discussing IRS Appeals Office's consideration of the "hazards of litigation"). 
settling. ${ }^{17}$ However, the existence of the $\$ 3,000$ settlement range in the example depends on certain implicit assumptions: (1) the parties' estimates of the trial outcome are identical, ${ }^{18}(2)$ the parties have symmetric stakes in the litigation, ${ }^{19}(3)$ the parties are risk-neutral ${ }^{20}$ and (4) the parties do not engage in strategic behavior in negotiating the division of the costs they will save by not going to trial. ${ }^{21}$ Deviations from any of these assumptions can eliminate a settlement range in some cases, depending on the magnitude of the deviation from the assumptions in relation to the stakes and the litigation costs. ${ }^{22}$

\section{B. The Predictions of Case-Selection Models}

If tried cases are those that deviate from one or more of the assumptions underlying the basic model reflected in the example above, are the deviations random or are they systematic and predictable? Scholars have intuited for some time that tried cases might differ

${ }^{17}$ Of course, the economic model ignores psychological factors that may prevent settlement even where it would be economically justified. See generally Korobkin \& Guthrie, supra note 11 (explaining the psychological barriers to a negotiated settlement).

${ }_{18}$ See Gross \& Syverud, Getting to No, supra note 12, at 324 ("ilf plaintiffs and defendants always agreed in their predictions of trial outcomes, there would be no trials at all."). In fact, if all cases settled, the parties would not have the same information on which to base their expectations of the outcome and might have more difficulty reaching a settlement because of the absence of applicable precedent. See supra note 11 and accompanying text.

${ }_{19}$ If a party has reputational stakes in the litigation, he will not only be motivated by the pure economic concerns of the single litigation. See Priest \& Klein, supra note 1 , at 27 . The example discussed in the text assumes not only symmetry of stakes but also that the only economic concerns are those of the single litigation, not the precedential effect of the possible trial outcome of the case as well. See infra notes 34-35 and accompanying text.

${ }^{20}$ See supra note 16 (defining risk-neutrality).

${ }^{21}$ Strategic bargaining over the division of the settlement range $(\$ 3,000$ in our example) can prevent settlement. Strategic behavior is posturing by a party to capture more of the surplus created by the settlement range. See Gross \& Syverud, Getting to No, supra note 12, at 328; Robert H. Mnookin \& Lewis Kornhauser, Bargaining in the Shadow of the Law: The Case of Divorce, 88 YALE LJ. 950 (1979).

For example, in the example discussed above, see supra text accompanying note 16 , the plaintiff was willing to settle for anything over $\$ 6,000$. For strategic purposes, however, he might maintain that he would not settle for anything less than $\$ 8,000$. If the defendant also behaves strategically, perhaps protesting that he would not pay more than $\$ 5,000$, the parties might fail to settle despite the existence of a genuine settlement range between $\$ 6,000$ and $\$ 9,000$.

The model also ignores the effects of attomeys, see generally Ronald J. Gilson \& Robert H. Mnookin, Disputing Through Agents: Cooperation and Conflict Between Lawyers in Litigation, 94 ColUM. L. REV. 509, 512 (1994); see also infra notes 116-33 and accompanying text (discussing the possible effects of attorneys). It also ignores the externalities of court opinions in a precedent-based system. See Bruce H. Kobayashi, Case Selection, External Effects, and the Trial/Settlement Decision, in DISPUTE RESOlUTION: BRIDGING THE SETTLEMENT GAP 17, 17 ( David A. Anderson ed., 1996) (stating that trials may occur because the effect of current litigation on future litigation may eliminate a settlement range); see also Cooter \& Rubinfeld, supra note 5, at 1070 .

${ }^{22}$ See, e.g., Jeffrey M. Perloff et al., Antitrust Settlements and Trial Outcomes, 78 REV. OF ECON. \& STATS. 401 (1996) ("Failure to settle may occur for at least three reasons. First, the plaintiff's expected gains may outweigh the defendant's expected losses either because the plaintiff believes its probability of winning is greater than does the defendant, or because the plaintiff expects a larger award at trial than does the defendant. Second, one or both parties might enjoy taking risks, or their lawyers may have a financial interest in the hours generated by a trial. Third ... 'breakdowns' of the settlement bargaining process may occur when parties have informational asymmetries ...."). 
systematically from cases that settled. ${ }^{23}$ Beginning with Priest and Klein's landmark article, ${ }^{24}$ scholars have used formal economic models to predict the selection of specific types of cases for trial, given certain assumptions. In fact, each of the formal models of settlement allows a deviation from one of the assumptions of the basic model of suit and settlement that was illustrated by the numerical example above, while holding the other assumptions constant. ${ }^{25}$ Each of these models predicts a different selection of cases for trial, but, notably, all three of the formal models predict a nonrandom selection of cases for trial.

Priest and Klein's model is based on the "divergent expectations" of the parties; it allows deviation from the basic model's assumption that parties' estimates of the likely outcome at trial are identical. Their model allows for differences in opinion about the likely outcome based on self-serving estimation bias. ${ }^{26}$ By further assuming a certain distribution of the parties' errors in making those estimates, ${ }^{27}$ and by maintaining the other assumptions of the basic model-that is, risk-neutrality, equal stakes and the absence of strategic behavior-Priest and Klein predict in their basic model ${ }^{28}$ that the "close" cases (those closest to the standard of decision in the case) will be disproportionately selected for trial. ${ }^{29}$ The "implication" of

${ }^{23}$ See, e.g., KARL N. LLEWELLYN, THE BRAMBLE BUSH: ON OUR LAW AND ITS STUDY 58 (1960) (stating that litigated cases bear the same relationship to the underlying pool of disputes "as does homicidal mania or sleeping sickness, to our normal life."), quoted in Priest \& Klein, supra note 1 , at 2.

${ }_{25}$ Priest \& Klein, supra note 1.

${ }^{25}$ See supra note 16 and accompanying text.

Each of the models allows a deviation from one of the assumptions of (1) identical party outcome estimates, (2) symmetric stakes, (3) risk-neutrality or (4) lack of strategic behavior, while maintaining the other three assumptions. See Gross \& Syverud, Getting to No, supra note 12 , at 324 ("I]f plaintiffs and defendants always agreed in their predictions of trial outcomes, there would be no trials at all.").

${ }^{26}$ The Priest/Klein approach is a type of "optimism" model because it bases parties' different estimates in the expected outcome of a trial not on asymmetric information, but on mere differences in opinion, given identical information. See Gertner, supra note 3, at 81, 81 n.20. Party "pessimism" about the likely outcome at trial would in fact increase the settlement range, see id. at $81 \mathrm{n.19}$, so the only possible reason trials could be caused by estimation errors is if parties are systematically biased in favor of over-estimating the chances of a favorable outcome. Such "optimism" can occur because each party might tend to estimate trial outcomes through a lens that resolves uncertainty in his favor.

${ }^{27}$ The Priest/Klein model assumes that in estimating the likely trial outcome, the parties make random estimation errors that are independent of each other, normally distributed and with a mean of zero. The model requires the assumption that the parties' errors in estimating outcome are homoskedastic, that is, that the error does not vary according to how close the case is to the decision standard. See Kobayashi, supra note 21 , at 23 n.18.

${ }^{28}$ Priest and Klein also consider the effect of differential stakes to the parties. See Priest \& Klein, supra note 1 , at $24-29$. Under their model, litigation is relatively more likely when the party with the greater stakes has a higher probability of winning. See id. at 25.

${ }_{29}$ In the basic Priest/Klein model, damages are stipulated and there are only two possible trial outcomes: liability (in which the defendant is required to pay the plaintiff the stipulated stakes, say $\$ 10,000$, as damages) and non-liability (in which the defendant pays nothing to the plaintiff). See id. at 17 . For example, if damages are stipulated at $\$ 10,000$, and the plaintiff will win the $\$ 10,000$ only if the defendant is found negligent, "negligence" is the decision standard. Priest and Klein postulate that a particular dispute might have any degree of liability-indicative facts. Any particular dispute, therefore, will lie somewhere on the scale that the decision standard divides into a zone of liability and a zone of non-liability. The "decision standard" is the 
this theory is that the plaintiff will win $50 \%$ of tried cases (again, assuming fixed stakes). ${ }^{30}$ Priest and Klein tested the "50 percent implication" on a data set of contested civil cases and found support for their theory, ${ }^{31}$ but other scholars' studies on different data sets generally have not supported the 50 percent implication. ${ }^{32}$

Subsequent to the Priest and Klein study, other scholars advanced alternative theories of the nonrandom selection of cases for trial. Asymmetric information models, also based on divergent expectations by the parties, allow party estimates of outcome to differ not based on party optimism but based instead on information held by only one party (asymmetric information), so that one side has a truer estimate of the likely outcome at trial. Unlike Priest and Klein's model, which predicts that the close cases will be tried, asymmetric information models predict that the "easy" cases will go to trial because the party with the information will only settle where he knows he has a weaker than average case; other cases will tend to go to trial ("adverse selection"). ${ }^{33}$

A third model of case selection, less well known, focuses on the possibility of unequal stakes, specifically in the context of the value of the precedent that results from trial. This model assumes no estimation errors, and maintains the other assumptions of the basic model. The model predicts, based on certain additional assumptions, that cases that go to trial will tend to be those in which the legal rule is inefficient ${ }^{34}$ or, where the parties' stakes are unequal, those cases in

rule dividing those cases in which the decision-maker will find the defendant liable from those cases in which he will not. Under Priest and Klein's assumptions, the cases selected for trial are disproportionately those closest to the decision standard in the case (the "selection effect") because estimation errors will be greater in those cases. See id.

It is implicit in Priest and Klein's model that the decision-maker will always accurately determine on which side of the decision standard a particular dispute lies, and that no disputes fall on the line. In other words, any error by the decision-maker is already factored into the location of the decision standard. Therefore, although it may appear to litigants that outcomes in cases closest to the decision standard are "as uncertain as coin tosses," Keith N. Hylton, Fee Shifting and Predictability of Law, 71 CHL-KENT. L. REV. 427, 436-37 (1995), in fact, the outcome is always certain, it is just unknown to the parties until the decision-maker announces the decision.

${ }^{30}$ The 50 percent implication results from Priest and Klein's assumption that filed cases are distributed approximately symmetrically around the decision standard and that tried cases are disproportionately those closest to the decision standard. See Kobayashi, supra note 21, at 21.

${ }_{31}^{31}$ Priest \& Klein, supra note 1, at 33.

${ }^{33}$ See infra note 37.

33 Adverse selection can occur under asymmetric information models because the party with private information has an incentive to accept a settlement offer from the uninformed party only if the chances that the informed party will win at trial are less than those of the average litigant. See Miller, supra note 14 , at 72.

${ }^{34}$ See Paul H. Rubin, Why Is the Common Law Efficient?, 6 J. LEGAL STUD. 51, 54 (1977). In the model it is applied to, the current liability rule requires a particular party (such as the defendant) to bear the costs of avoidance and future liability. If the suit is litigated and the plaintiff wins, the liability rule remains the same, so avoidance and liability costs are unchanged. On the other hand, if the defendant wins, the liability rule will be reversed, so that the defendant no longer bears those costs, and the plaintiff must bear them. Under the model, the process will continue, if both sides have a substantial interest in precedents, until the liability rule is on the low-cost avoider, who will find it less expensive to avoid liability than to litigate. 
which the outcome is disproportionately likely to favor the "repeat player," that is, the party with an interest in establishing a precedent. ${ }^{35}$

\section{Difficulties in Testing the Models}

The prediction of each of these models for which cases will be selected for trial flows directly from the restrictive assumptions under the respective model. If, for example, the only cause of trials is party estimation error based on optimism, and if Priest and Klein's assumption that party estimation error is systematic is valid, then the cases that fail to settle will be the cases closest to the applicable "decision standard," as Priest and Klein predict. The prediction follows directly from the assumptions, so in order to test Priest and Klein's hypothesis on actual cases, a study would need to either test whether the assumptions hold true within the data set or whether the prediction based on the assumptions is borne out by the data. Of course, neither approach is realistic. It is unlikely that there is one sole cause of trials, and similarly unlikely that assumptions such as risk-neutrality, equal stakes and lack of strategic bargaining are true of every case in a data set. Empirical studies of Priest and Klein's hypothesis reflect this problem: many scholars have tested the 50 percent implication of

Thus, cases that go to trial will disproportionately be those where the law inefficiently places liability on the high-cost avoider.

If the model is correct in predicting which cases will go to trial, and if there is a positive probability that inefficient liability rules will be reversed at trial, this model implies that the law will evolve towards efficiency over time. The evolution toward efficiency implication has been questioned by some scholars. See, e.g., Robert Cooter \& Lewis Kornhauser, Can Litigation Improve the Law Without the Help of Judges?, 9 J. LEGAL STUD. 139, 153-54 (1980) (noting that such factors as strategic bargaining can cause cases to go to trial whether the resulting precedent is efficient or inefficient); Cooter \& Rubinfeld, supra note 5 (stating that economic models of legal change demonstrated only a weak tendency towards efficiency); Georg von Wangenheim, The Evolution of Judge Made Law, 13 INT L REV. L. \& ECON. 381, 382-83 (discussing why public choice theory must be considered in hypothesizing which legal rules are challenged in the judicial process). However, the validity of asymmetric information as an explanation for why some cases go to trial does not depend on the evolution toward efficiency implication because of the additional assumptions required for the implication to hold.

${ }^{35}$ See Kobayashi, supra note 21 , at 37 (noting that the selection of cases "is biased toward those cases likely to result in holdings favorable to the repeat litigant. . ."); Rubin, supra note 34, at 55; see also Frank B. Cross, The Precedent-Setting Value of Litigation and the Selection of Cases for Trial (unpublished working paper on file with author) (arguing precedentsetting value of a case plays a major role in selection of cases for trial).

If only one party has a substantial interest in the precedent resulting from trial, cases that go to trial will not be those that reflect inefficient liability rules, but rather those cases likely to result in holdings favorable to repeat litigants. Bruce Kobayashi uses the following example: Assume that two similarly situated plaintiffs proceed sequentially and independently against a common defendant. In the first action, the plaintiff faces no external effects but the defendant does because of the effect precedent in the first trial will have on the second trial. See Kobayashi, supra note 21, at 37 ("The one-sided demand for precedent will cause there to be asymmetric stakes to litigation, causing the defendant to spend more on litigation than the plaintiff, and tilting the distribution of trial outcomes toward defendants."). As demonstrated by the numerical example above, see supra text accompanying note 16 , in a situation in which only the defendant faces external gains from a favorable trial outcome, as the external gains generated by the defendant from a trial victory increase, the case is more likely to go to trial. Conversely, as the defendant's estimate of the plaintiff's likelihood of prevailing increases, or the defendant's external cost of losing at trial increases, the case will be less likely to go to trial. See Kobayashi, supra note 21 , at 37 . Thus, tried cases will be disproportionately selected from those with holdings that are likely to favor repeat litigants. 
Priest and Klein's hypothesis, ${ }^{36}$ and have found that it does not hold. ${ }^{37}$ However, other scholars have noted that this does not disprove Priest and Klein's "selection effect" theory because deviations from the 50 percent prediction can always be explained by deviations from the underlying assumptions. ${ }^{38}$

Testing the real-life applicability of the suit and settlement models more directly than by simply examining plaintiff victory rates is even more difficult. First, it is difficult to obtain information about settled cases, ${ }^{39}$ and with only tried cases in a sample, it is impossible

${ }^{36}$ See Gross \& Syverud, Getting to No, supra note 12, at 325 ("To a remarkable extent, this 'fifty percent implication,' which Priest also describes as the 'principle [sic] empirical heuristic of the model,' has come to overshadow the more general selection effect.") Id. at 327 ("However limiting its assumptions, the fifty percent hypothesis has the virtue of being easy to remember, and apparently easy to test. It seems that such tests require only information about trial outcomes, which are much more accessible to researchers than settlement negotiations. And tested the fifty percent hypothesis has been, on datasets [sic] as diverse as wrongful death cases in Japan, civil rights cases in federal courts, challenges to federal agency decisionmaking, and state court appellate decisions. The tests, however, are often unsatisfying. On the one hand, a finding of a fifty percent success rate is too rarely accompanied by an inquiry into whether the underlying assumptions of the model are actually met. On the other hand, a deviation from a fifty percent rate can almost always be explained as a failure of one or more of these essential assumptions rather than a failure of the hypothesis itself.") (citation omitted).

Disproving the 50 percent implication disproves the specific selection effect developed by Priest and Klein. However, proof of the 50 percent implication is strong evidence of the selection effect but does not rule out the possibility of a $50 \%$ victory rate occurring by chance.

${ }^{37}$ See, e.g., Daniel Kessler et al., Explaining Deviations from the Fifty Percent Rule, $25 \mathrm{~J}$. LEGAL STUD. 233, 236-42 (1996) (reviewing over 20 articles that have found that plaintiff success rates do not approximate 50\%); see also Kevin M. Clermont \& Theodore Eisenberg, Trial by Jury or Judge: Transcending Empiricism, 77 CORNELL L. REV. 1124 (1992) (stating that only 22 of 93 categories of bench trial cases show plaintiff success rates of between $45 \%$ and $55 \%$; only 16 of 93 categories of jury trial cases show plaintiff success rates of between $45 \%$ and 55\%); Patricia Munch Danzon \& Lee A. Lillard, Settlement Out of Court: The Disposition of Medical Malpractice Claims, 12 J. LEGAL STUD. 345 (1983) (demonstrating a 26.8\% plaintiff success rate); Theodore Eisenberg, Testing the Selection Effect: A New Theoretical Framework with Empirical Tests, 19 J. LEGAL STUD. 337, 339 (1980) (concluding data are inconclusive); Eisenberg, supra note 3, app. A (finding only 16 of 73 subject matter categories show plaintiff success rates of between $45 \%$ and 55\%); Theodore Eisenberg \& Sheri Lynn Johnson, The Effects of Intent: Do We Know How Legal Standards Work?, 76 CORNELL L. REV. 1151, 1172 (1991) (finding a 40\% plaintiff success rate); Gross \& Syverud, Getting to No, supra note 12, at 333 (finding a $51.4 \%$ plaintiff success rate); Priest \& Klein, supra note 1, at 33 (showing plaintiff success rates of $45.6 \%, 49.5 \%$ and $53.0 \%$ ); J. Mark Ramseyer \& Minoru Nakazato, The Rational Litigant: Settlement Amounts and Verdict Rates in Japan, 18 J. LEGAL STUD. 263, 28185 (1989) (finding plaintiff success rates of 78\% and $81.9 \%$ ). See generally Gross and Syverud, Getting to No, supra note 12, at 327 (criticizing 50 percent implication); Vicki Schultz \& Stephen Patterson, Race, Gender, Work, and Choice: An Empirical Study of the Lack of Interest Defense in Title VII Cases Challenging Job Segregation, 59 U. CHL. L. REV. 1073 (1992) (finding plaintiff success rates of $49.2 \%$ and $46.3 \%$ ); Donald Wittman, Dispute Resolution, Bargaining, and the Selection of Cases for Trial: A Study of the Generation of Biased and Unbiased Data, 27 J. LEGAL STUD. 313, 345 (1988) (finding plaintiff success rates of $83 \%$ and 84\%). But cf. Joel Waldfogel, The Selection Hypothesis and the Relationship Between Trial and Plaintiff Victory, 103 J. POL. ECON. 229, 230 (1995) (finding empirical support for a selection effect under the Priest/Klein model).

${ }^{38}$ See Kobayashi, supra note 21, at 27 (stating that lack of empirical support for the 50 percent implication in data sets of actual cases is not surprising, given the strong assumptions behind it); see, e.g., Siegelman \& Donohue, supra note 3, at 429-30 (stating deviations from the 50 percent rule in actual data sets might be explained by cases that are disputes over damages rather than liability, thus inflating plaintiff observed win rates, and by differential stakes, which, as predicted by Priest and Klein, would lead to systematic deviations from a $50 \%$ plaintiff success rate).

${ }^{39}$ See Wittman, supra note 37, at 345 ("Most disputes are settled out of court, but the characteristics of these disputes and the amounts settled upon are rarely known to the public."); cf. Gross \& Syverud, Getting to No, supra note 12, at 324-25 ("Since [Priest and Klein's theory] 
to determine how the cases that settled differ from the cases that went to trial. ${ }^{40}$ This may explain the extent of scholars' focus on Priest and Klein's 50 percent implication, ${ }^{41}$ which only requires a look at outcomes in tried cases. Second, the same problem of controlling for the limiting assumptions of a model quickly arises. ${ }^{42}$ Third, evaluating the accuracy of the model would depend on judgment calls such as how close a case was to the "decision standard" or whether the facts of a particular case favored a party with private information or a repeat player. Thus, empirical studies of which cases settle have generally been limited to inconclusive tests on tried cases of Priest and Klein's 50 percent implication. ${ }^{43}$

The three models discussed above are the most formal frameworks for predicting which cases go to trial. However, there are other theories for why cases go to trial. In particular, some scholars hypothesize that principal-agent problems between parties and their at-

is a comparative assertion (cases tried are closer to the decision standard than cases settled), it requires data on both settlements and trials.").

${ }_{40}$ See, e.g, Gross \& Syverud, Getting to No, supra note 12, at 321 ("Our hope is to learn something about how pretrial bargaining works by examining those cases in which it did not work - a method similar, perhaps, to studying the operation of an assembly line by looking at the rejects."); Korobkin \& Guthrie, supra note 11 , at 119 n.48 ("There may be important subtleties about settlement that cannot be gleaned from examples of nonsettlement.").

${ }_{41}^{4}$ See supra note 37 and accompanying text.

42
See supra notes 36-37 and accompanying text; see also Kessler et al., supra note 37, at 233 (stating that multimodal case characteristics associated with violations of Priest and Klein's assumptions cause plaintiff win rates to deviate from the $50 \%$ result implied by Priest and Klein's theory).

${ }^{43}$ There are a few exceptions. Two suit and settlement studies used simulations, rather than actual cases, to test the underlying Priest/Klein hypothesis that cases closest to the "decision standard" are disproportionately selected for trial. See Linda R. Stanley \& Donald L. Coursey, Empirical Evidence on the Selection Hypothesis and the Decision to Litigate or Settle, $19 \mathrm{~J}$. LEGAL STUD. 145, 151-52 (1990) (using undergraduates to divvy up chips in an urn); Robert E. Thomas, The Trial Selection Hypothesis Without the 50 Percent Rule: Some Experimental Evidence, 24 J. LEGAL STUD. 209, 211 (1995) (using business school students and a computer program that simulated legal disputes).

One large study of private antitrust litigation on cases filed in five federal district courts used a follow-up survey to all of the parties or their attorneys that "yielded a limited amount of data on ... settlements." Steven C. Salop \& Lawrence J. White, Private Antitrust Litigation: An Introduction and Framework, in PRIVATE ANTITRUST LITIGATION: NEW EVIDENCE, NEW LEARNING 3-4 (Lawrence J. White ed., 1988). That data was used to simulate the effect on settlement of reducing the treble damages multiplier. See Perloff \& Rubinfeld, supra note 9, at 149. That study revealed differences in which cases settled that depended on the nature of the plaintiffs and defendants involved. See id. at 162-63. However, some of the cases characterized as "settlements" in that data set were dismissals that may actually have been defendant victories. See Salop \& White, supra, at 11 . Moreover, the survey results probably did not give a random sample of settled cases. Perloff, Rubinfeld and Ruud also used the data to develop a model of determinants of trial outcome. See Perloff et al., supra note 22, at 401 . In that study, they dropped certain types of cases that may not have been true settlements. See id. at 404 n.10.

In the context of medical malpractice, Danzon and Lillard found in part that the propensity to litigate increases with the size of the potential verdict and decreases if there are limits on contingent fees. Danzon \& Lillard, supra note 37 , at 365,366 . Their study focused on presenting estimates of a model of disposition of medical malpractice claims, despite unobserved variables requiring estimates. See id. at 346 . The data was drawn from two surveys of insurance company claims, which they describe as "broadly representative but not strictly randomized samples of claims against physicians and hospitals." Id. at 354.

Also in the context of medical malpractice, Farber and White found that cases with negligent care were much less likely to be dropped before the lawsuit stage than cases with good care. See Henry S. Farber \& Michelle J. White, A Comparison of Formal and Informal Dispute Resolution in Medical Malpractice, 23 J. LEGAL STUD. 777, 797 (1994). 
torneys can cause cases to fail to settle. ${ }^{44}$ Similarly, strategic bargaining can preclude settlements. In addition, certain techniques may facilitate settlement, such as alternative dispute resolution (ADR) procedures and judicial "activism" in encouraging settlement. Since these theories have not been formally modeled, they have not been tested in controlled studies.

\section{Which Cases Go to Trial?: The Study of TAX Court CASES}

In contrast to prior work, the study that is the focus of this Article was performed on a data set of cases of which approximately half settled and the other half went to trial. ${ }^{45}$ The data consisted of a random sample of about 400 recent cases docketed in Tax Court. ${ }^{46}$ These cases present an unusual opportunity to test for nonrandomness of trials because, unlike most courts, the Tax Court keeps records of settled cases. ${ }^{47}$

In order to avoid the problem of limiting assumptions that are not true of actual cases, and the problem of subjective judgments about the merits of a case, the study tested for nonrandomness by comparing the attributes of tried cases in the sample with the attributes of settled cases in the sample. This approach allows a major advance in testing whether cases go to trial or settle randomly. More specifically, the study tested whether any of nine characteristics of a case were statistically significant predictors ${ }^{48}$ of the type of outcome-trial or settlement. ${ }^{49}$ As discussed below, the nine variables

44 See infra notes 117-33 and accompanying text.

${ }^{43}$ The data in this study reflect two possible outcomes: trial or settlement. A settlement is a case in which the Tax Court enters a "stipulated decision." See infra note 47. It is possible that one or more settlements occurred during or after trial, but before the judge's decision in the case. Such cases would be reflected as stipulated decisions, and therefore, settlements. However, for simplicity, this Article refers to settlements as having occurred prior to trial.

${ }^{46}$ See Appendix A for an explanation of data-collection techniques; see Appendix D for a description of the data.

${ }^{47}$ In Tax Court, if the IRS and the taxpayer agree on a settlement figure in a docketed case, their agreement is put in the form of a written stipulation. This stipulation is filed with the Tax Court, which enters its decision in accordance with it, as a "stipulated decision." See RIA FEDERAL TAX CoORDINATOR 2d II T-1909 (1988). The Tax Court retains the full file in that case for one year after entry of the stipulated decision. See infra note 158 and accompanying text. I refer to cases in which a stipulated decision was entered by the Tax Court as "settled" cases. The remaining cases in my sample are opinion decisions, which I refer to as "tried" cases.

${ }^{48}$ As with any study on actual disputes, my data could not directly test whether any of the models correctly predicts which cases go to trial. However, as discussed below, the study results do allow inferences about the applicability of the theoretical models to Tax Court cases. See infra notes 136-51 and accompanying text.

49 As explained below, the predictive effect of each variable, controlling for the other variables, was done using a statistical technique called multiple regression analysis. See Appendix $B$. Performing a multiple regression analysis requires selecting only some of the multitude of characteristics that are possible trial predictors because including too many variables can preclude measurement of the characteristics that are valid predictors. See Mark A. Hall et al., Judicial Protection of Managed Care Consumers: An Empirical Study of Insurance Coverage Disputes, 26 SETON HALL L. REV. 1055, 1066 (1996) ('Including too many factors can reduce the utility of the analysis because several of the factors are likely to be measuring the same 
were chosen by considering what factors might influence settlement in Tax Court, based on the Tax Court litigation process and on theories about factors that might influence the selection of cases for trial. ${ }^{50}$ The statistical technique of multiple regression analysis was used to test whether any particular case feature or features, controlling for other aspects of the case, indicated an increased likelihood that the case would go to trial..$^{51}$

In selecting variables as possible trial predictors, it is important to consider the characteristics of cases in the data set. The cases used in this study were all docketed Tax Court cases, so they share certain attributes, and also differ from each other in specific ways. It is these differences, such as whether the taxpayer is represented or pro se, that can be used to test whether cases go to trial randomly. Each of the nine variables used in the study, "STAKES," "APPEALS," "JUDGETYPE," "DECADE," "BACKGROUND," "PARTY," "TAXPAYER," "REGION" and "COUNSEL,"52 reflects a characteristic of either the case itself, the taxpayer involved in the case or the judge assigned to the case.

The Tax Court exclusively hears civil federal tax cases. ${ }^{53}$ Most of the cases are "deficiency" cases in which the Internal Revenue Service (IRS) has mailed the taxpayer a "notice of deficiency,",54 informing the taxpayer that the IRS has determined that the taxpayer under-reported its tax liability, ${ }^{55}$ in response to which the taxpayer has Prior to the notice of deficiency, the taxpayer, whose return was peti-

phenomenon at once. In such an event, most or all of the factors will appear insignificant, even though in combination they explain a great deal of the observed variation in outcome.").

${ }^{50}$ Cf. Perloff \& Rubinfeld, supra note 9, at 164 ("We hypothesize that the settlement gap is a function of the characteristics of the case and the litigants as well as differences in the courts (which may vary by jurisdiction and over time).").

${ }_{51}^{5}$ See Appendix B for an explanation of this statistical procedure.

52 Each of the variables had two to six parameters. Because the variables I used have values that fall into categories, rather than ranges of values (such as special trial judge or regular judge), each independent variable had a reference group and one or more additional groups. See generally MICHAEL O. FINKELSTEIN \& BRUCE LEVIN, STATISTICS FOR LAWYERS 358 (1990). See Appendix $C$ for a list of the variables and the groups within each independent variable. Although STAKES (dollar amount at stake) could have been analyzed as a continuous variable, it was treated as a categorical variable by dividing the cases into four categories that roughly correspond to the categories generally used in discussions of Tax Court cases.

${ }^{53}$ Approximately $95 \%$ of litigated civil federal tax cases are heard by the Tax Court. See Leandra Lederman, "Civil"izing Tax Procedure: Applying General Federal Learning to Statutory Notices of Deficiency, 30 U.C. DAVIS L. REV. 183, 185 (1996); Hon. David Laro, The Evolution of the Tax Court as an Independent Tribunal, 1995 U. ILL. L. REV. 17, 18 (1995); Hon. Theodore Tannenwald, Jr., The Tax Litigation Process: Where It Is and Where It Is Going, 44 REC. ASS'N B. CTTY N.Y. 825, 827 (1989). The other 5\% go to the United States Court of Federal Claims or the United States District Courts. See id.

${ }^{54}$ MICHAEL I. SALTZMAN, IRS PRACTICE AND PROCEDURE (2d ed. 1991) II 8.06[5][a]. I.R.C. $\$ 6212$ (a) authorizes the notice of deficiency. See I.R.C. \$ 6212(a) (1997).

${ }_{35}$ For Tax Court jurisdiction, the taxpayer must petition the Tax Court in response to the notice of deficiency. See Lederman, supra note 53 , at $185,185 \mathrm{n} .13$. If a taxpayer petitions the Tax Court without having received a notice of deficiency, the court will dismiss the case for lack of subject matter jurisdiction. See I.R.C. \& 6213(a) (1997) (requiring notice of deficiency for Tax Court jurisdiction). 
tioned the Tax Court. ${ }^{56}$ STAKES generally reflects the deficiency amount in the notice.

Prior to the notice of deficiency, the taxpayer, whose return was audited, ${ }^{57}$ likely received a "30-day letter"58 from the IRS, ${ }^{59}$ which notified him of the right to request an administrative appeal from the IRS Appeals Office in response to the letter. ${ }^{60}$ The Appeals Office is explicitly authorized to consider the "hazards of litigation," and considers its mission to be the settlement of cases; ${ }^{61}$ it settles approximately $90 \%$ of the cases it considers, ${ }^{62}$ and it sends a notice of deficiency only to taxpayers whose cases do not settle. ${ }^{63}$ If a taxpayer does not respond to the 30-day letter, the Appeals Office will send a notice of deficiency. The taxpayer has 90 days from the date of the notice of deficiency to petition the Tax Court. ${ }^{64}$ Docketed Tax Court

${ }^{56}$ See supra note 55; see also Lederman, supra note 53, at 195 (explaining Tax Court subject matter jurisdiction).

${ }^{57}$ Taxpayers are selected for audit based on a complex formula with a multitude of variables, called the DIF (discriminant function). See SALTZMAN, supra note 54, II 8.03[1], [2]. Variables used in the DIF are developed from a Taxpayer Management Compliance Program (TCMP), which the IRS has conducted approximately once every three years. See id. II 8.03[1][b]. Data from the TCMP is used to develop variables for the DIF that are the most likely to target returns with the greatest possibility of error. See id. All returns selected by the DIF are examined manually by a trained professional before they are selected for audit. See id. II 8.03[1][a].

58 SALTZMAN, supra note 54, II 8.03[1][a]; Treas. Reg. \$ 601.105(d)(1)(iv) (1998).

59 This assumes that the auditing agent did not accept the return as filed, and that the taxpayer did not concede the case at the administrative level; for the case to be properly docketed in Tax Court, the taxpayer must have received a notice of deficiency and petitioned the court. See supra note 55.

${ }^{60}$ The 30-day letter informs the taxpayer of his right to request a conference with the IRS Regional Office of Appeals. See supra note 55. When the tax deficiency is more than $\$ 10,000$, the request must include a written protest explaining the taxpayer's position. See Treas. Reg. $\S$ 601.105(d)(2)(iii) (1998).

The Appeals Office is of course an office within the administrative agency that initiated the dispute, the IRS. This may result in bias on the part of Appeals Office in favor of the IRS. See Philip Elman, Administrative Reform of the Federal Trade Commission, 59 GEO. L.J. 777, 778 (1971); Richard A. Posner, The Behavior of Administrative Agencies, 1 J. LEGAL STUD. 305,324 (1972). One implication of such bias might be a tendency to settle few cases, if that were seen as a sign of IRS error in sending a 30-day letter. See Posner, supra, at 324-25. The IRS Appeals Office, however, apparently views its mission as settlement, see infra note 61, and settles the overwhelming majority of its cases, see George Guttman, IRS Averages: Winning Little, Losing Big, 61 TAX NoTES 155, 156 (Oct. 11, 1993) ("Unless there is an IRS policy to the contrary, the hearing Officer in the Appeals Office makes a settlement offer on the basis of the quality of the case set up by the auditor and the hazards of litigation. For example, if the Officer thinks that the IRS has only a 30-percent chance of succeeding in litigation, an offer will be made to settle the case for 30 cents on the dollar.").

${ }^{61}$ INTERNAL REVENUE MANUAL 8131 (2), MT 8-188 (Jan. 9, 1989) (Appeals Mission).

62 See Guttman, supra note 60, at 156 ("On the whole, the IRS disposes of about 90 percent of the cases by settlement. In fiscal 1992, it settled 67,251 out of 74,591 appealed cases.").

${ }^{63}$ See 26 C.F.R. $\$ 601.106$ (d)(2)(ii) (1998). The IRS Appeals Office settles approximately $90 \%$ of its cases, so cases that have not yet been to the Appeals Office and are referred there by the Tax Court might be more likely to settle than those that made it out of the Appeals Office without settling. See JAMES E. MERRITT, ADMINISTRATIVE PROCEDURES: REPRESENTATTON BEFORE THE IRS APPEALS OFFICE, SB47 ACI-ABA 89 (Oct. 17, 1996).

${ }^{64}$ See I.R.C. \$ 6213 (1997); SALTZMAN, supra note 54, I1 9.03[3]. Filing a petition commences the Tax Court case. See TAX CT. R. 20. Cases in this study, both settled and tried, reflect those in which the taxpayer chose to petition the Tax Court in response to the notice of deficiency.

If the taxpayer does not file a Tax Court petition, the taxpayer can either pay, effectively conceding the case, or pay and claim a refund, prolonging the dispute with the possibility of suing for a refund in district court or the Court of Federal Claims if the claim is denied. See 
cases that bypassed the Appeals Office are referred there for possible settlement. $^{65}$ The APPEALS variable reflects whether the case went to the Appeals Office prior to docketing (where it must have failed to settle in order to be included in the sample) or post-docketing.

The Tax Court is an Article I court ${ }^{66}$ so all of its trials are bench trials. ${ }^{67}$ Four of the study's variables focused on characteristics of the judge assigned to the case. ${ }^{68}$ JUDGETYPE reflects whether the case was assigned to a Tax Court judge or to a Special Trial Judge. Special Trial Judges, appointed by the Chief Judge of the Tax Court, hear most of the "small tax cases," cases involving informal procedures for disputes involving dollar amounts limited by statute, ${ }^{69}$ and they hear

Lederman, supra note 53 , at $186 \mathrm{n} .11$. If the taxpayer does not pay the tax or petition the Tax Court in response to a statutory notice, the IRS can assess the tax and, after notice and demand from the IRS, the taxpayer will be obligated to pay the tax. See I.R.C. $\$ 6213$ (c). In order for a refund court to have jurisdiction over a refund suit, the taxpayer must first have made full payment of the tax assessed. See Flora v. United States, 362 U.S. 145 (1960); Shore v. United States, 9 F.3d 1524 (Fed. Cir. 1993). The taxpayer must also file a timely refund claim with the IRS. See I.R.C. \$ 7422(a) (1997); United States v. Dalm, 494 U.S. 596, 601-02 (1990); see also I.R.C. $\$ 6511$ (1997) (setting a limitation on claims for credits or refunds for overpayment of taxes). The taxpayer can not file suit until either six months have elapsed from the time he filed the claim or when the IRS sends a notice of disallowance of the claim. See I.R.C. $\$ 6532$ (1997).

${ }^{65}$ See Rev. Proc. 87-24, 1987-1 C.B. 720; SALTZMAN, supra note 54, II 9.03 [4]. The Appeals Office retains sole jurisdiction over the case until IRS District Counsel requests return of the file to prepare for trial. See Smith, supra note 16, at 77. A 1986 General Accounting Office study found that $62 \%$ of the cases closed in 1984 where the taxpayer had initially bypassed the Appeals Office were eventually settled by the Appeals Office. Increased use of IRS' Appeals process prior to Tax Court Petition Recommended by GAO Study, RIA WEEKLY ALERT (Sept. $11,1986)$.

${ }^{66}$ See I.R.C. $\$ 7441$ (1997); Tax Reform Act of 1969, Pub. L. No. 91-172 § 951, 83 Stat. 730 (1969). It is the successor to the Board of Tax Appeals, also an Article I court. See Revenue Act of 1942, ch. 619, $\$ 504$ (a), 56 Stat. 957 (1942) (providing for a name change from the "Board of Tax Appeals" to "The Tax Court of the United States").

${ }^{67}$ See I.R.C. § 7459(b) (1997); William F. Nelson \& James J. Keightley, Managing the Tax Court Inventory, 7 VA. TAX REV. 451,453 (1988). The court is located in Washington, D.C., but the judges travel for regular calendars in cities around the country. See I.R.C. $\$ 7446$ (1997). The small case division was established by the Tax Reform Act of 1969. See Pub. L. No. 91-172 $\$ \$ 957$ (a), 960 (a), (b) and (f). The Tax Court hears small cases in several additional cities. See I.R.C. § 7453; TAX CoURT R. 177(a).

${ }^{68}$ Because of the relatively large number of judges in the sample relative to the number of cases collected, it was not possible to test the effect of each individual judge on case outcome. Testing each of the nine independent variables separately assumes independence of each variable from the other. Because many judges in the sample decided more than one case each, that assumption was technically violated. However, grouping judges by four specific characteristics mitigated the problem of lack of independence.

${ }^{69}$ Code section 7463 authorizes special proceedings (the "S procedure") for petitions filed with the Tax Court where neither the amount of the deficiency placed in dispute (including additions to tax) nor the amount of any claimed overpayment exceeds $\$ 10,000$ for any one taxable year. See I.R.C. \& 7463(a)(1), (e) (1997) (prior to 1998 amendment). This section also allows the $S$ procedure where neither the amount of the deficiency placed in dispute nor the amount of any claimed overpayment exceeds $\$ 10,000$ in the case of any tax imposed by chapter $11 ; \$ 10,000$ for any one calendar year, in the case of any tax imposed by chapter 12 ; or $\$ 10,000$ for any one taxable period or taxable event in the case of any tax imposed by subtitle $D$ which is described in section 6212 . The "small case" division uses less formal procedures in return for a waiver of the right of appeal. See I.R.C. \& 7463; HON. SAMUEL B. STERRETT, UNITED STATES TAX COURT: ITS ORIGIN AND FUNCTIONS 7 (1986). Code section 7463 was amended in 1998 to increase the dollar limit from $\$ 10,000$ to $\$ 50,000$. See I.R.C. \$ 7463 (1997) (amended 1998).

The taxpayer essentially has the unilateral option to elect this procedure; it is-not by agreement of the parties, so it is not equivalent to a partial settlement. $C f$. Samuel R. Gross, Settling for a Judge: A Comment on Clermont and Eisenberg, 77 CORNELL L. REV. 1178, 1180 (1992) (stating that in cases in which bench trial is not mandatory, in effect it requires both parties' agreement and thus represents a partial settlement). Because the Tax Court would not 
other cases as well. ${ }^{70}$ In any case involving more than the statutory dollar limit, a Special Trial Judge's opinion must be adopted by a regular judge. ${ }^{71}$ Those opinions are publicly available, but opinions in small tax cases are generally written as Summary Opinions, which generally have not been available to the public, ${ }^{72}$ so fewer opinions by Special Trial Judges are publicly available than those decided by regular Tax Court judges.

DECADE, BACKGROUND and PARTY also reflect judge characteristics. DECADE is the decade in which the judge was appointed to the bench; BACKGROUND is his pre-Tax Court background: private sector, government or both; PARTY is the political party of the President who appointed the judge, or, in the case of Special Trial Judges, of the President who appointed the Chief Judge who appointed the Special Trial Judge. ${ }^{73}$

TAXPAYER reflects whether the taxpayer was an individual, corporation or estate. REGION reflects the region of the country the taxpayer resided in at the time he filed the Tax Court petition. Region might ex ante be significant because the IRS is represented in Tax Court by attorneys in District Counsels' offices around the country. In addition, although the Tax Court is a national court, Tax Court decisions may be appealed to the court of appeals for the circuit in which the taxpayer resided at the time he filed the Tax Court petition. ${ }^{74}$ If that court of appeals has decided a case squarely on point on a particular issue, that precedent is applicable in Tax Court. ${ }^{75}$

Finally, COUNSEL reflects whether the taxpayer appeared pro se or was represented by counsel. Taxpayers may be represented by members of the Tax Court Bar, who may be attorneys, or other individuals who have passed an examination. Each of these nine variables was used in an equation that tested the predictive effect of each

release files or opinions in small cases, I could not collect specific data on these cases. See Leandra Lederman, Tax Court $S$ Cases: Does the 'S' Stand for Secret?, 79 TAX NOTES 257 (1998). Instead, I could only obtain aggregate data obtained from the IRS under the Freedom of Information Act (FOIA). See 5 USC \& 552 (1997). I could not obtain similar information under FOIA from the Tax Court because FOIA applies only to administrative agencies, not courts. See 5 USC 552 (a), (f)(1) (stating that section 552 applies to "agencies" as defined in section $551(1)(B) ;$ " "the courts of the United States" are excluded from the definition of "agency").

See I.R.C. \& 7443A (1997) (amended 1998).

7 See I.R.C. \& 7443A(c); TAX CT. R. 183(c).

72 Because files and opinions in small tax cases are not disclosed to the public during the period in which I conducted this study, no small tax cases were included in this study. See supra note 69.

${ }_{73}$ Because the PARTY and DECADE variables interacted, runs were done with an "interaction term" to control for the effect of the interaction. See Appendix F. The interaction was not surprising, because DECADE reflects the decade in which a judge was appointed to the bench and PARTY reflects the political party of the appointing President, a variable that changes every four years at most. The interaction term proved not to be statistically significant, and therefore not helpful, so further runs were done without that term.

${ }_{75}$ See I.R.C. § 7482(b) (1997).

${ }^{75}$ See Golsen v. Commissioner, 54 T.C. 742 (1970), affd on other grounds, 445 F.2d 985 (10th Cir. 1971). If there is no precedent squarely on point in the circuit to which appeal would lie, the Tax Court can apply its own rule. See id. 
on the outcome variable, TRIAL. That is, statistical analyses tested whether, controlling for the other variables mentioned, a case with higher stakes, for example, would have an increased likelihood of going to trial. ${ }^{76}$

\section{STUDY RESULTS AND IMPLICATIONS FOR CASE-SELECTION MODELS}

As shown in Appendix E, Analysis of the Tax Court data studied revealed that five of the nine independent variables, APPEALS, STAKES, JUDGETYPE, DECADE and BACKGROUND, were statistically significant in predicting an increased likelihood that a case would go to trial. ${ }^{77}$ Thus, the data demonstrated a nonrandom selection of cases for trial: Tried cases were statistically different from settled ones. The specific results are even more interesting in that they provide insights into the mechanisms at work in Tax Court, which in turn illuminates the applicability of the various theoretical models to other kinds of cases.

\section{A. The Study Results and Insights into the Models}

Cases that had been through the Appeals Office prior to being docketed in Tax Court were about four times more likely to go to trial ${ }^{78}$ than cases that had not been to the Appeals Office prior to docketing. ${ }^{79}$ This tends to indicate that the IRS' internal dispute

${ }^{76}$ Specific results of the analyses are reported in Appendix E.

77 See Appendix E. The nonrandomness result agrees with Perloff and Rubinfeld. See Perloff \& Rubinfeld, supra note 9, at 166, 167 (finding that certain variables were statistically significant in predicting settlement in their data of private antitrust litigation). However, Perloff and Rubinfeld's data were from the data set on private antitrust litigation, where information on settlements was gleaned from party surveys that was not necessarily reflective of the underlying pool of cases used in the study. See supra note 43.

${ }^{78}$ The APPEALS variable was the most statistically significant predictor of settlement in the data set, with a $p$-value of .0000 .

The results for the APPEALS variable are consistent with aggregate statistics on Tax Court cases, which reflect that fewer of the Tax Court petitions arise out of notices of deficiency sent by the Appeals Office than by notices sent by the Examination Division of the IRS or its Service Centers. See U.S. TAX COURT JUDICIAL CONF. (1997) (showing that for fiscal year $1990,3,702$ dockets arose out of Appeals Office notices of deficiency, 12,250 arose out of those sent by the Examination Division, 10,485 arose out of those sent by Service Centers, and 1,911 were unreported; numbers are similar for other years reported, 1991 through 1994).

The results discussed in this section are reported in the chart in Appendix E. That chart provides a side-by-side comparison of five representative statistical runs. The APPEALS variable was not included in all runs because that reduced the usable sample size to approximately 342 cases. See infra note 180 . However, it was used in the final model, Model 5 in Appendix E, as well as many of the models used to arrive at the final model. Runs on the set of 342 cases were very consistent with runs on the larger pool. See Appendix E. For a description of the full set of 479 cases and the subset of 342 cases, see Appendix D.

${ }^{79}$ Cases having been through the Appeals Office's pre-docketing process without settling were approximately four times as likely to go to trial as cases that had not been through the Appeals Office's pre-docketing process. See Appendix E, Models 4, 5 (showing that cases that did not go though a pre-docketing IRS appeal were .24 or .26 times as likely to go to trial as cases that had been through a pre-docketing IRS appeal). 
resolution process is effective. ${ }^{80}$ That is, there were relatively few cases that were settled during dealings with district counsel attorneys in Tax Court that were capable of settlement but were prevented from earlier settlement because of the dynamics in the Appeals Office. This result is consistent with scholars' reasoning that alternative dispute resolution might facilitate parties' understanding of their cases, and therefore reduce estimation errors, ${ }^{81}$ or help prevent lawyer-client agency problems. $^{82}$ It might also help prevent strategic behavior. Although the strategic behavior model does not suggest the nonrandom selection of a particular type of case for trial, scholars have theorized that familiarity with the opponent may reduce the possibility of a bargaining breakdown. ${ }^{83}$ This is consistent with the theory that increased information about the other party's risk preference and estimates of success and the amount of damages helps temper strategic behavior.

The direction of the STAKES result-that higher stakes cases were much more likely to go to trial-is quite informative. If risk aversion increased with the stakes involved, this would suggest that higher stakes cases settle disproportionately, ${ }^{84}$ a result which in fact did not occur. On the other hand, optimism models and asymmetric information models, both of which are models based on parties" "divergent expectations" about trial outcomes, postulate that parties fail

Because some of the independent variables that eventually determine the trial or settlement outcome may also determine whether a taxpayer brought the case to the Appeals Office prior to docketing it in Tax Court, the inclusion of APPEALS as an independent variable may produce simultaneous equations bias. See Peter Kennedy, A GuIDE To ECONOMETRICS 126-45 ( 2 d ed. 1985). The lack of suitable instrumental variables precluded the standard instrumental variables approach as a treatment for this problem. See id. at 133. As an alternative, I ran an equation similar to Model 1 in Appendix B, but with a dependent variable that allows four possible outcomes: (1) pre-docketing appeal, settle in Tax Court; (2) pre-docketing appeal, Tax Court trial; (3) no pre-docketing appeal, settle in Tax Court; and (4) no pre-docketing appeal, Tax Court trial. This equation was estimated using a multinomial logistic procedure. See id. at 191. The results indicated no substantive differences from the results of the binomial logistic regression, except that results for COUNSEL indicated that represented taxpayers were more likely to have a pre-docketing appeal than unrepresented taxpayers.

${ }^{80}$ However, taxpayers know that if they do not go to the Appeals Office prior to filing in a Tax Court, the case will be sent there afterwards. See Rev. Proc. 87-24, 1987-1 C.B. 720. It is possible that some taxpayers wait to settle their cases until they are in the Appeals Office.

81 "Although particular methods of alternative dispute resolution ... vary from one another, they share the feature that a third party is involved who offers an opinion or communicates information about the dispute to the disputants." Shavell, supra note 8 , at 1 .

${ }_{82}$ See id. at 21 ("It is sometimes suggested as well that ADR might furnish clients a unique chance to understand the character of their cases and thereby help to defeat client-lawyer agency problems. Whatever is the truth of the matter, it warrants investigation."). See infra notes 116-33 and accompanying text for a discussion of lawyer-client agency problems.

${ }^{83}$ See Stephen McG. Bundy, The Policy in Favor of Settlement in an Adversary System, 44 HASTINGS L.J. 1, 15 (1992); Robert Cooter et. al., Bargaining in the Shadow of the Law: A Testable Model of Strategic Behavior, 11 J. LEGAL STUD. 225, 232-33, 241 (1982); cf. Gross \& Syverud, Getting to No, supra note 12, at 327 (noting that data did not bear out the hypothesis that repeat players were tougher bargainers; defendant insurance companies were not more intransigent bargainers than plaintiffs).

$C f$. Perloff \& Rubinfeld, supra note 9, at 160 (" $[R]$ isk-averse parties are more likely to settle a given case than risk-neutral parties. If risk aversion increases with the magnitude of the losses involved, a reduction in the damages multiplier will reduce the amount of risk and therefore, other things equal, increase the likelihood that the case will go to trial."). 
to settle when their estimates of the expected outcome at trial differ to such an extent as to preclude a settlement range, ${ }^{85}$ that is, a difference of greater than or equal to the sum of the parties' litigation costs. ${ }^{86}$ Divergent expectations theories suggest that cases with higher stakes may be more difficult to settle (assuming litigation costs remain fixed) because the same difference in opinion translates into a larger difference in the expected outcome of the case. ${ }^{87}$ The results for STAKES supports divergent expectations theory and the importance of estimation errors to the settlement/trial decision. The results may reflect that litigation costs do not rise proportionately to the stakes, thus magnifying the effects of estimation differences at higher stakes levels. $^{89}$

Theoretically, higher stakes could indicate a case with higher precedential value, although it is unlikely that the two characteristics are perfectly correlated. However, in general, taxpayers disproportionately win higher stakes cases, thus suggesting that the "repeat player" version of the external effects model is not being played out in Tax Court. In fact, the value of a Tax Court precedent to the IRS is

${ }^{85}$ See Shavell, supra note 8, at 11 ("If the defendant believes the plaintiff's chances of winning are less than 40 percent, there will not be room for settlement since then the defendant will pay less than $\$ 4,000+\$ 2,000=\$ 6,000$ in settlement, which is the least the plaintiff would accept."). In other words, "[w] tend to be disputes in which the two sides' estimates are relatively far apart." Thomas, supra note 43, at 222; see also Priest and Klein, supra note 1 , at 16 (stating that where difference between parties' probability estimates of outcome is small, they are more likely to settle than where difference is large).

Using the numbers in the example discussed above, see supra text accompanying note 16 , assume, as above, that if the suit goes to trial, the plaintiff will receive $\$ 10,000$ if he wins, and that he estimates a $70 \%$ probability of winning. Assume trial costs to plaintiff and defendant of $\$ 1,000$ and $\$ 2,000$, respectively. Based on the plaintiff's estimate of a $70 \%$ chance of receiving $\$ 10,000$, and the $\$ 1,000$ cost to go to trial, he will settle for anything above $\$ 6,000$. However, if, unlike the above example, the defendant estimates that the plaintiff has only a $30 \%$ likelihood of winning $\$ 10,000$, the defendant would not be willing to settle the case for more than $\$ 5,000$ (the sum of his estimate of the expected outcome, $\$ 3,000$ and his expected litigation costs, $\$ 2,000$ ). Thus, divergent estimations of the expected value of the case eliminated a settlement range in this example.

${ }_{86}$ See Trubek, supra note 2, at 76 n.9 (citing John P. Gould, The Economics of Legal Conflicts, 2 J. LEGAL STUD. 279, 285-88 (1973)); see also Steven Shavell, Suit, Settlement, and Trial: A Theoretical Analysis Under Alternative Methods for the Allocation of Legal Costs, $11 \mathrm{~J}$. LEGAL STUD. 55, 63 (1972) (providing a numerical example of the absence of a settlement range resulting from divergent expectations of the likely trial outcome).

${ }^{87}$ See Shavell, supra note 8, at 14 . However, if one or both parties were risk-averse, cases with higher stakes might be more likely to settle. The government, a repeat player that does not bear its own costs, may be risk-neutral. However taxpayers, choosing between "losses" may be risk-averse. See Jeffrey Rachlinski, Gains, Losses, and the Psychology of Litigation, 70 S. CAL. L. REV. 113 (1996).

${ }^{8}$ Litigation costs might not rise proportionately to the stakes because the largest cost, attorneys fees, may not rise proportionately with stakes because in Tax Court cases attorneys are paid by the hour (not on a contingency basis). Cf. Claudio Riedi, Comment, To Shift or to Shaft: Attorney Fees for Prevailing Claimants in Civil Forfeiture Suits, 47 U. MIAMI L. REV. 147, 181 n.160 (1992) ("Litigation costs do not usually increase proportionally to the increase in the stakes.".

${ }_{8}$ In other words, as discussed above, the parties might be able to reach agreement in a $\$ 3,000$ settlement range where the stakes were $\$ 10,000$ but not reach agreement in the same settlement range if the stakes were $\$ 100,000$ or $\$ 1,000,000$. 
not particularly significant because of the fact that the Tax Court follows any circuit precedent squarely on point. ${ }^{90}$

The importance of several of the judge variables supports the literature on the importance of judges to the conduct of litigation. ${ }^{91}$ Scholars have recognized that judges have a strong influence over the way litigation is conducted. ${ }^{92}$ Theoretically, a judge might determine not only the actual outcome of a case, ${ }^{93}$ but also might influence whether a case settles or when it settles. ${ }^{94}$ "Advocates of judicial participation in settlements insist this involvement ultimately saves court time by disposing of cases that would otherwise go to trial." Even during the time that judges did not engage in active case management, most cases settled without trial, ${ }^{96}$ but, if one current hypothesis is true, the trend in favor of "activist" (or "managerial") judges $^{97}$ might indicate that more recently appointed judges settle a greater percentage of their cases.

If more recently appointed judges are more likely to be "activist," was appointed to the bench, lends support to the hypothesis that ac-

${ }^{90}$ See supra note 75.

91 See, e.g., Peter H. Schuck, The Role of Judges in Settling Complex Cases: The Agent Orange Example, 53 U. CHI. L. REV. 337 (1986).

92 See, e.g., Alexander, supra note 2, at 566; Resnick, supra note 2, at 376-77 ("Many federal judges have departed from their ... relatively disinterested pose to adopt a more active, 'managerial' stance. In growing numbers, judges are not only adjudicating the merits of issues presented to them by litigants, but also are meeting with parties in chambers to encourage settlement of disputes and to supervise case preparation. Both before and after the trial, judges are playing a critical role in shaping litigation and influencing results.").

${ }^{3}$ Political science research indicates that judges make decisions in furtherance of their ideologies. See, e.g., Robert A. Dahl, Decision-Making in a Democracy: The Supreme Court as a National Policy-Maker, 6 J. PUB. L. 279 (1957); Tracey E. George \& Lee Epstein, On the Nature of Supreme Court Decisionmaking, 86 AM. POL. SCr. REV. 323 (1992); Jeffrey A. Segal \& Albert D. Cover, Ideological Values and the Votes of U.S. Supreme Court Justices, 83 AM. POL. SCL. REV. 557 (1989).

94. See Marc Galanter, Reading the Landscape of Disputes: What We Know and Don't Know (and Think We Know) About Our Allegedly Contentious and Litigious Society, UCLA L. REV. 4, 8-9 (1983) (stating that those courts that were most intensely involved in settlement were the slowest courts); Carrie Menkel-Meadow, For and Against Settlement: Uses and Abuses of the Mandatory Settlement Conference, 33 UCLA L. REV. 485, 494 (1985).

The mean time to decision in the subset of 342 cases was 744 days from filing of the petition. The shortest time in that sample was 15 days, and the largest was 4249 days. I collected time information but did not use it as an independent variable for this study because it is more likely that the type of decision (opinion or settlement) indicates the relative length of time to decision than the reverse. That is, cases that go to trial are likely to reflect a longer time to disposition not because the time factor itself indicates an increased likelihood that a case will be tried, but rather that it takes longer for a case to go to trial than for a case to settle prior to trial. However, the time data could be useful in examining whether attorneys delay or accelerate disposition of a case.

${ }^{95}$ William L. Adams, Comment, Let's Make a Deal: Effective Utilization of Judicial Settlements in State and Federal Courts, 72 OR. L. REV. 427, 427 (1993) (citing HUBERT L. WILL ET AL., THE ROLE OF THE JUDGE IN THE SETTLEMENT PROCESS (1977)).

${ }^{6}$ See Charles E. Clark \& James Wm. Moore, A New Federal Civil Procedure: Pleadings and Parties, 44 YALE L.J. 1291, $1294 \mathrm{n} .8$ (1935) (stating that a study showed that approximately $70 \%$ of all civil cases filed in federal court did not reach a judge or jury decision).

${ }^{97}$ For a discussion of "managerial judges," see Resnick, supra note 2, at 386-414. See also Clermont \& Eisenberg, supra note 37.

98 Anecdotal evidence suggests that some of the more recently appointed Tax Court judges are particularly activist in encouraging parties to settle. 
tivist judges facilitate settlements. As a group, judges and Special Trial Judges appointed in the 1980s were significantly less likely to have a case go to trial than judges appointed in the 1960s or 1970s. Results for judges appointed in the 1990s, for which there was much less data, were not statistically significant, ${ }^{100}$ although they too were less likely than judges appointed in the 1960s and 1970s to have a case go to trial. ${ }^{101}$

BACKGROUND also supports the importance of judicial characteristics on whether a case settles or goes to trial. Cases before judges with a government background were more likely to go to trial than those with a private sector background. That is, judges from private practice may be more "activist" in promoting settlement. However, cases before judges with experience in both government and the private sector were less likely to go to trial than cases before judges with a private sector background. This may indicate that the parties' estimations of trial outcomes were more likely to overlap where the judge had both types of experience before appointment to the bench. ${ }^{102}$ It is also possible that judges whose prior experience enabled them to "see both sides" pushed harder for settlement or that their efforts to facilitate settlement were taken more seriously because the judge had credibility with both parties.

The fact that cases before Special Trial Judges were significantly more likely to go to trial than cases before regular judges might reflect the fact that parties have less information from which to form estimates of trial outcomes in cases before Special Trial Judges because many opinions authored by Special Trial Judges are unpublished "Summary Opinions" in small tax cases. ${ }^{103}$ Thus, increased information about the judge's decision-making would increase the likelihood of settlement. ${ }^{104}$ In addition, the data may reflect that parties accord less weight to settlement pressure from Special Trial Judges as they do to regular judges. If true, this would support the

\footnotetext{
${ }^{99}$ The reference group was the 1960 s to 1970 s. For example, in the run with 342 cases, including the APPEALS variable but not PARTY, judges and Special Trial Judges appointed in the $1980 \mathrm{~s}$ were .354 times as likely as the reference group to have a case result in an opinion decision.

${ }^{100}$ The $95 \%$ confidence interval included 1 , so it is possible that there was no increased or decreased likelihood of trial in cases before judges appointed in the 1990 s and the reference group of judges appointed in the 1960s-1970s. See infra note 176 and accompanying text (explaining confidence intervals that include 1).

Oil Judges appointed in the $1990 \mathrm{~s}$ were .594 times as likely as the reference group to have cases result in an opinion decision, but that result was not statistically significant; the $95 \%$ confidence interval included 1 , which means that the relationship could have occurred by chance. See infra note 176 and accompanying text.

${ }_{102}$ It is also possible that this result simply reflects the fact that the groups are made up of relatively few judges so that, since judge effects are important, the $p$-value is low, but the log odds number reflects a blending of characteristics other than the judge's work background.

${ }_{103}$ See supra note 72 and accompanying text.

${ }^{104}$ It is also possible that trial costs are lower in cases heard by Special Trial Judges than by regular judges. This is unlikely, however, because none of the cases in the sample were small tax cases.
} 
importance of judicial activism in promoting settlements. However, it is possible that this result reflects either a nonrandom assignment of cases to Special Trial Judges as a group ${ }^{105}$ or the fact that cases settled before a judge is assigned are entered as stipulated decisions by the Chief Judge, which overstates the number of cases settled by regular judges. ${ }^{106}$

Overall, the importance of the judge variables indicates that judges affect which cases settle. ${ }^{107}$ Activist judges may assist the parties or their attorneys in overcoming some barriers to settlement. ${ }^{108}$ It is possible, for example, that activist judges give parties more information about the likely outcome at trial, 109 or discourage "optimism," "which reduces parties' estimation errors, or helps parties avoid strategic behavior ${ }^{11 \mathrm{f}}$ or lawyer-client agency problems. ${ }^{112}$ In fact, some Tax Court judges telephone parties prior to trial and ask them about the nature of settlement discussions, ${ }^{113}$ schedule a pre-trial

${ }^{105}$ For example, repeat players among taxpayers would have an incentive not to elect the small tax case procedure for stronger cases, in order to end up with a published precedent, and to elect the procedure for weaker cases. Even for larger cases, repeat players could, at least in theory, request assignment of the case to a Special Trial Judge. However, if this phenomenon occurred, the results that a greater percentage of cases before Special Trial Judges go to trial than cases before regular judges suggests that cases disfavoring repeat players were disproportionately tried, contrary to the predictions of the external effects model. It also suggests that the party with private information about the strength of the case-the repeat player-was not settling weaker cases, which is consistent with the asymmetric information model but not the Priest/Klein model.

${ }_{106}$ Cases are assigned to trial calendars as soon as possible after joinder of issue. See TAX CT. R. 131. In deficiency cases, issue is generally joined once the IRS has filed its answer, unless a reply is required. See TAX CT. R. 38. It is possible that the number of cases settled by regular judges is overstated in my data set because cases that settled before they were assigned to a particular judge's trial calendar were apparently entered by the Chief Judge (by definition a regular judge) as stipulated decisions. However, many of those cases in the data set that settled so early were missing information on many variables, and were therefore not included in most of the regressions. Unfortunately, my data did not allow me to distinguish between those cases on the Chief Judge's trial calendar that settled and those that settled before they were assigned to a particular calendar.

${ }^{107}$ The PARTY variable was not statistically significant, which is consistent with the results of another study. See Ashenfelter et. al., supra note 3, at 281.

${ }_{103}$ However, a study of federal district court cases found only minor judge effects on whether a case settles. See id. at 272 . In that study, cases before judges appointed by Republican Presidents were more likely to have settled than cases before judges appointed by Democratic Presidents, but the results were not statistically significant. See id. at 276-77. In addition, increased settlements could be the result of judges' bias toward settlement, which would not involve countering party pessimism or lawyers' irrational fear of trial, for example. See Bundy, supra note 83 , at 70 .

${ }_{109}$ See Shavell supra note 8, at 21.

${ }^{110}$ See Bundy, supra note 83 , at 70 ("L] the need to 'throw cold water' on the parties to reduce unwarranted optimism and the measures designed to achieve that purpose. ...") (citations omitted).

11 A "facilitator" judge strives to prevent strategic breakdowns in bargaining and encourage settlement where there is a settlement range. See id. at 60-61; see also infra notes 113-15, (providing examples of how a Tax Court judge may facilitate settlement).

${ }_{112}$ A "counselor" judge may review each party's factual and legal claims with the party and his lawyer in order to expose its weaknesses. This may help control lawyer-client conflicts of interest that would otherwise hinder settlement. See Bundy, supra note 83, at 63-64.

${ }^{113}$ See Smith, supra note 16, at 80 ("It is quite common that a judge will speak to the parties on a conference telephone call prior to the trial and question them about settlement discussions, and even as to the nature of the parties' settlement positions."). 
conference to discuss settlement ${ }^{114}$ or even solicit settlement offers from the parties and ascertain if there is a settlement range. ${ }^{115}$

Unlike the foregoing judge variables, the COUNSEL variable was not statistically significant. ${ }^{116}$ Its lack of importance as a trial predictor tends to undermine various theories about the effects of attorneys on litigation, unless counsel influence different cases in opposite and offsetting ways. ${ }^{117}$ On the one hand, scholars suggest that consulting an attorney may improve a party's estimation of the trial outcome, and may mitigate some of the self-serving estimation bias that underlies the theory of the optimism model. ${ }^{118}$ However, clients might sometimes ignore an attorney's recommendation to settle because of uncertainty about the attorney's ability to estimate the likely trial outcome. ${ }^{119}$ Moreover, although the standard economic models discussed above ignore the presence of attorneys, ${ }^{120}$ the presence of attorneys imposes principal-agent problems on the basic economic model of dispute resolution. ${ }^{12}$ Some researchers argue that because attorneys' interests might at times diverge from their clients' interests, ${ }^{122}$ attorneys' economic incentives might influence which cases

${ }^{114}$ See id. ("If the parties are reluctant to discuss their case on the telephone, or if the judge feels an in-person discussion would be more productive, the judge may schedule a pretrial conference under Rule 110, or a meeting between the parties in chambers. ... Probably the most common meeting in chambers, however, occurs after the calendar call on the first day of a trial session in a city outside Washington. Usually, if either party requests a chambers conference, or if the judge thinks one would be helpful, the parties privately sit down with the judge and they mutually explore settlement. In the typical chambers conference, the judge first will ask each party to explain its case and how it expects to prove that case. After both sides have spoken, the judge may try to focus them on mutual areas of agreement or suggest a procedure for coming to agreement. The judge also may ask the parties if they would be interested in hearing the judge's tentative views on how he or she would rule in the case, assuming the parties presented the evidence they said they would present.").

${ }^{115}$ See id. ("A less common form of mediation that the judges employ in chambers conferences is to ask the parties if they would be willing to inform the judge of their settlement ranges without the other party being present. After the parties jointly discuss the case with the judge, the judge will speak to the parties separately (often with a law clerk present as a witness) to learn their settlement ranges. If the judge sees an overlap in those ranges, he may call the parties back into the room jointly and tell the parties that an overlap exists and even suggest a settlement number that both parties could live with.").

${ }^{116}$ The COUNSEL variable reflects whether the taxpayer was represented in Tax Court at any time. In collecting the data, if the CCH Tax Court Petitions Digest, the actual petition, if it was available, or, for trials, the opinion itself, reflected the presence of an attorney (or other representative), that was noted. If it was known that the taxpayer was not represented during the entire pendency of the case, that was also noted, but the taxpayer was treated as represented for purposes of the COUNSEL variable.

${ }_{117}$ See infra notes 118-33 and accompanying text.

118 It is unlikely to completely eliminate the effects of party optimism, however. See Bundy, supra note 83, at 19; Elizabeth F. Loftus \& Willem A. Wagenaar, Lawyers' Predictions of Success, 28 JURIMETRICS J. 437 (1988).

${ }^{119}$ See Thomas, supra note 43 , at 225 ("Clients sometimes force trials by refusing to accept attorneys' recommendations to settle. In such disputes, the attorney's estimation error is exacerbated by a client's uncertainty about the attorney's evaluation of the dispute's probability of success.")

${ }_{120}^{120}$ See Gilson \& Mnookin, supra note 21.

${ }_{121}$ See Cooter \& Rubinfeld, supra note 5, at 1070.

${ }^{122}$ See, e.g., Bundy, supra note 83 , at 19, 19 n.76 (arguing that lawyers' interests may diverge from clients" for such reasons as "fee arrangements, personal identification with or revulsion for the client or her cause, obligations to other clients, desire to curry favor with prospective clients, or concern for reputation, whether with other lawyers, the tribunal, or the wider public"); Frank B. Cross, The Role of Lawyers in Positive Theories of Doctrinal Evolution, 45 
settle. ${ }^{123}$ First, attorneys paid by the hour may have an incentive to continue to litigate a case that could be settled, postponing or even precluding settlement. ${ }^{124}$ On the other hand, contingency-fee attorneys might have an economic incentive to settle cases early, ${ }^{125}$ even when that is not in the client's best interest. ${ }^{126}$ However, these effects might indicate only when a case will settle, not whether it will settle. Existing research indicates that those lawyers who practice on a contingency fee basis are more likely to settle cases than those paid by the hour, ${ }^{127}$ but those effects are generally found to be marginal in data sets of actual cases. ${ }^{128}$ In Tax Court cases, attorneys typically charge by the hour, rather than on a contingency basis, probably because functionally the taxpayer is defending ${ }^{129}$ against a tax liability asserted by the IRS. ${ }^{130}$

EMORY L.J. 523, 544-46 (1996); Gross \& Syverud, Getting to No, supra note 12, at 349-52; Geoffrey P. Miller, Some Agency Problems in Settlement, 16 J. LEGAL STUD. 189, 201 (1987); Angela Wennihan, Let's Put the Contingency Back in the Contingency Fee, 49 SMU L. REV. 1639,1651 (1996) ("An attorney's interests are generally aligned with the client's because the common goal is to extract a large settlement or verdict from the defendant. The interests diverge, however, because the attorney maximizes her net profit by working as few hours as possible to reach this large result, whereas the client wants the attorney to work as many hours as necessary to attain this goal."). But cf. Trubek et. al., supra note 2, at 108 (demonstrating that hourly fee lawyers and contingency fee lawyers did not spend statistically different amounts of time on cases, even when comparing hours per event or hours per dollar at stake).

${ }_{123}$ See, e.g., Gertner, supra note 3 , at 79 (postulating that explanations for failure to settle might include attomeys advising clients to make low settlement offers or reject settlement offers if the attorney can make more money by litigating).

${ }_{124}$ See, e.g., Gilson \& Mnookin, supra note 21, at 513, 527-29; Miller, supra note 14 , at 189-90; Cross, supra note 122, at 556 (quoting Robert H. Gertner \& Geoffrey P. Miller, Settlement Escrows, 24 J. LEGAL STUD. 87, 98 (1995)); Rachlinski, supra note 87, at 172 (stating that avaricious hourly-fee lawyers could discourage settlement by framing the settlement offer as a loss); cf. Lisa Bernstein, Understanding the Limits of Court-Connected ADR: A Critique of Federal Court-Annexed Arbitration Programs, 141 U. PA. L. REV. 2169, 2195 (1993) ("A lawyer paid on an hourly basis has a strong incentive to encourage his client to request a trial [after mandatory non-binding $A D R]$ since most legal fees are eamed during discovery and trial."). $189-90$.

${ }^{125}$ See, e.g., Gilson \& Mnookin, supra note 21, at 513, 527-29; Miller, supra note 14 , at

${ }^{126}$ See Wennihan, supra note 122 , at 1655 ("The lawyer and the client have the same interests only when the case goes to the jury; before that time the attorney actually has a strong incentive to settle the case, which could be in conflict with the plaintiff's best interests.") (citation omitted).

${ }_{127}$ See Terry Thomason, Are Attomeys Paid What They're Worth? Contingent Fees and the Settlement Process, 20 J. LEGAL STUD. 187, 189-90, 215-22 (1991); cf. Bernstein, supra note 124, at 2195 (arguing that where the client has a right to a trial de novo, "a contingency-fee lawyer has a strong incentive to encourage his client to accept an arbitration award").

${ }_{128}$ See, e.g., Bundy, supra note 83 , at 20 (stating empirical evidence on whether hourly fee and contingency fee lawyers yield to incentives to follow their own interests is ambiguous) (citing Herbert M. Kritzer et. al., The Impact of Fee Arrangement on Lawyer Effort, 19 L. \& SOC'Y REV. 251 (1985)); Gross \& Syverud, Don't Try, supra note 12, at 54 ("We do not doubt that plaintiffs' attorneys ... . sometimes act in conflict with the best interests of the parties. But we do not believe that such conflicts (strategic or otherwise) are a common cause of trials $\ldots$ [In their survey of attorneys,] no defense attorney said that there was no settlement because the plaintiff's attomey wanted a shot at a major verdict. ..."); see also Kessler et. al., supra note 37, at 248 (stating agency effects on the decision to litigate or settle are theoretically indeterminate).

${ }_{20}$ See Lederman, supra note 53, at 193-94. Technically, however, the taxpayer is the plaintiff. See id.

${ }_{130}$ That is, even if the taxpayer wins the case entirely, he will generally not collect anything, but rather will be relieved of a liability to the IRS. This is true unless the Tax Court finds that the taxpayer made an overpayment of tax, which occasionally happens. See I.R.C. $\S 6512(\mathrm{~b})(1)$ (1997) (granting Tax Court jurisdiction over overpayments). 
On the other hand, attorneys may be able to mitigate strategic behavior that might prevent settlement. ${ }^{131}$ That is, it is possible that attorneys enable clients to settle cases their clients could not settle on their own, ${ }^{132}$ perhaps because of reputational concerns as repeat players that clients may not have. ${ }^{133}$

The lack of significance of the REGION variable indicates that anecdotal evidence that some district counsels' offices are more willing to settle cases than others might be unfounded. In addition, although individual taxpayers were slightly more litigious than corporate taxpayers, the results for the TAXPAYER variable were not statistically significant. This tends to indicate that risk-aversion by individuals was not a strong indicator of the settlements that did occur. ${ }^{134}$ It also suggests that individuals in the sample were not disproportionately litigious. ${ }^{135}$

${ }^{131}$ In addition, some commentators have argued that pro se litigants file frivolous cases, or use legal process to harass others. See, e.g., Jeffrey M. McLaughlin, Note, An Extension of the Right of Access: The Pro Se Litigant's Right to Notification of the Requirements of the Summary Judgment Rule, 55 FORDHAM L. REV. 1109, 1109 n. 4 (1987) (listing cases in which pro se litigants used litigation to harass others); Eric J.R. Nichols, Note, Preserving Pro Se Representation in an Age of Rule 11 Sanctions, 67 TEX. L. REV. 351, 351 n.3 (1988) (listing further cases in which pro se litigation was used to harass others).

Commentators also assert that, where only one side is represented, pro se litigants are substantively disadvantaged, at least in small claims court. See, e.g., Thomas L. Eovaldi \& Peter R. Meyers, The Pro Se Small Claims Court in Chicago: Justice for the 'Little Guy'?, 72 NW. U. L. REV. 947, 987 tbl. VIII (1978) (finding that where defendant was represented, plaintiff won $68.8 \%$ of cases; where defendant was not, plaintiff won $85.4 \%$ of cases); Barbara Yngvesson \& Patricia Hennessy, Small Claims, Complex Disputes: A Review of the Small Claims Literature, 9 L. \& SOC'Y REV. 219, 250 (1975) (relating findings of unreported study); Mark S. Downing et al., Note, The Toledo Small Claims Court: Part 1, 6 U. TOL. L. REv. 397, 405-06 (1975); Hon. Tim Murphy, D.C. Small Claims Court-The Forgotten Court, 34 D.C.B.J. at 14, 15-16 (Feb. 1967); see also Richard N. Block \& Jack Stieber, The Impact of Attomeys and Arbitrators on Arbitration Awards, 40 INDUS. \& LABOR REL. REV. 543, 553-54 (1987) (describing how arbitration parties fared better with attorneys in discharge cases than without, particularly if the other side did not have an attorney; where neither side had an attorney, awards did not differ significantly from cases in which both had an attorney). Where each side has the option of hiring an attorney, the decision whether to do so might be viewed as a "prisoner's dilemma." However, in Tax Court, the IRS is always represented; only the taxpayer may be either represented or pro se.

${ }_{132}$ See Eovaldi \& Meyers, supra note 131, at 988 (showing that in the small claims court cases they studied, an appearance had been filed by an attorney in $26.2 \%$ of cases, but in cases settled on the day of trial, an attorney was present in $36.3 \%$ of the cases); Gilson \& Mnookin, supra note 21, at 512; see also Kessler et al., supra note 37, at 246 (arguing that contingency fee lawyers have an economic incentive to settle early on); $c f$. Rachlinski, supra note 87 , at 171, 172 (noting that lawyers might frame settlement offers as "gains" rather than "losses," thus encouraging the client to settle, or they might do the opposite); Trubek et al., supra note 2, at $104-05$ (stating that lawyers' pursuit of their own goals increases litigation costs); id. at 105 (noting that the study showed that client control of lawyers did not affect hourly or contingency fee lawyers' time investment in a case).

${ }^{33}$ Interestingly, in a study where attorneys were asked why cases that went to trial failed to settle, "[a] clear pattern emerged immediately: Each side says the other one did it." Gross \& Syverud, Don't Try, supra note 12, at 49.

${ }^{134}$ Common wisdom suggests that individuals are more risk-averse than corporations, assuming they bear their own costs. See, e.g., Gross \& Syverud, Getting to No, supra note 12, at 381 .

${ }^{135} \mathrm{Cf}$. Galanter, supra note 94, at 5-11 (discussing perception of our society as one of the most litigious in the world). Eisenberg and Farber looked at whether the type of legal entity involved in the litigation affected the plaintiff's win rate. Whether the taxpayer is an individual, corporation or some other entity theoretically could affect the likelihood of settlement. See 
In sum, the results tend to support the importance of information in parties' formation of expectations about the likely outcome at trial. The STAKES variable supports the importance of divergent expectations as possible causes of trials. The judge variables also suggest the importance of judge behavior in minimizing divergent expectations and strategic behavior. The APPEALS variable results also suggest that the parties settle early in cases in which they have similar expectations about the outcome. The lack of significance of the TAXPAYER and COUNSEL variables tends to indicate that risk preference and attorney-client agency problems are not significant causes of Tax Court trials.

\section{B. Generalizability of the Results to Other Civil Litigation}

The study results, while demonstrating a nonrandom selection of cases for trial in Tax Court, raise the issue of the generalizability of the results. In most respects, Tax Court cases are similar to other civil cases. Despite the similarities, specific trial predictors may be different in other types of litigation. ${ }^{136}$ In addition, Tax Court cases do differ from other cases in some ways. First, Tax Court cases are carefully selected from the underlying pool of tax disputes. Three fora have trial-level jurisdiction over federal civil tax cases: the Tax Court, the district courts, and the United States Court of Federal Claims. ${ }^{137}$ Although the tax jurisdiction of each is not entirely co-terminous, many litigated tax cases could be considered by any of the three fora; the Tax Court hears $95 \%$ of these cases, however, ${ }^{138}$ which minimizes this selection effect. Tax Court cases may also be heard in the court's small tax case division, ${ }^{139}$ and of course many tax cases never make it to court because they are resolved by the IRS Appeals Office before they are ever docketed. ${ }^{140}$ Thus, in interpreting the results of this study, the fact that Tax Court cases are probably not a random subset of all tax disputes must be considered. However, the study did control for size of the amount at stake, and whether the case had a predocketing IRS appeal. In addition, the fact that there are trial predictors even within a relatively homogenous and selected group of cases suggests that selection effects would be magnified if one were able to compare Tax Court cases with those that dropped out along the way to Tax Court. ${ }^{141}$

\footnotetext{
Theodore Eisenberg \& Henry S. Farber, The Litigious Plaintiff Hypothesis: Case Selection and Resolution, 28 RAND J. ECON. S92, S93 (1997).

${ }^{136}$ To use one example, certain variables selected for this study are court-specific, such as

JUDGETYPE (regular judge or Special Trial Judge).

137 See supra note 53.

138 See Lederman, supra note 53, at 185.

139 See supra note 68 and accompanying text.

140 See supra notes $60-62$ and accompanying text.
In addition, regressions using interaction terms for APPEALS by STAKES, AP-

PEALS by COUNSEL and APPEALS by JUDGETYPE did not generate $p$-values even close to
} 
Furthermore, unlike much other civil litigation, Tax Court disputes involve an administrative agency of the federal government, the IRS, as well as a private party, the taxpayer. This feature distinguishes Tax Court cases from other litigation in several ways. First, one side to each dispute is a repeat player, whereas the other party is unlikely to be a repeat player. The repeat player, the IRS, is likely to be risk-neutral, ${ }^{142}$ while taxpayers may vary in risk preference. Riskneutrality by one party results in a narrower settlement range, all other things being equal, than if that party were risk-averse. ${ }^{143}$ In addition, a repeat player has greater stakes in the litigation, ${ }^{144}$ which may affect the selection of cases for trial. ${ }^{145}$ That is, the repeat player may include the potential precedential value of an opinion decision in its calculus of whether to settle, while a one-shot player typically would not. ${ }^{146}$

In addition to being a repeat player, the IRS is an administrative agency charged with applying a federal statute. There is currently no formal model that predicts how government litigation, as opposed to other repeat-player litigation, may affect the selection of cases for trial, but there may be differences. ${ }^{47}$ The IRS may not internalize the cost of litigation the way the taxpayer does, since the government does not bear its own costs, ${ }^{148}$ which could lead to distortions in application of the economic analysis of whether to settle or go to trial. ${ }^{149}$ Furthermore, the government may be more successful at trial than

significance at the .05 level. This tends to indicate that cases considered by the Appeals Office prior to docketing in Tax Court are statistically similar to those not so considered during predocketing, with respect to STAKES, COUNSEL and JUDGETYPE, so that selection at the Appeals Office level did not affect the study's results.

${ }^{142}$ Repeat players are likely to be risk-neutral because, over a number of iterations, their actual trial results will approximate the expected trial results of cases in the pool.

${ }^{143}$ See supra note 16.

144 See Feirstein, supra note 15, at 207 ("[T] he [Internal Revenue] Service may gain the value of precedent by proceeding to trial. In addition, the Service's litigation costs are generally fixed and therefore less significant than the taxpayer's litigation costs. To determine the value of precedent, the Service multiplies the probability of a favorable precedent by the aggregate amount of deficiencies outstanding, and subtracts from that sum its litigation costs. The Service must then net this against the anticipated loss in revenues attendant to an adverse judgment. If the probability of a favorable judgment outweighs the particular tax liability at issue, resulting in a cost to settling before trial, the Service will attempt to force a trial rather than settle.") (footnotes omitted).

${ }^{145}$ See generally Priest \& Klein, supra note 1 (examining the relationship between litigated and settled cases).

${ }^{146}$ See supra note 19 and accompanying text; supra note 35 and accompanying text.

${ }^{147}$ Perloff and Rubinfeld noted that in their data of private antitrust litigation, without controlling for other differences among plaintiffs, plaintiffs that were organizations (such as unions or governmental agencies) settled many fewer cases than plaintiffs that were firms, although the difference was not statistically significant. In addition, their data revealed little difference in settlement rates among types of defendants. See Perloff \& Rubinfeld, supra note 9, at $163,182 \mathrm{n} .26$ (showing in a table that there is little variation in settlement rates by type of defendant).

${ }^{148}$ In addition, the IRS' litigation costs may be relatively fixed, regardless of whether or not it brings a specific case to trial. See Feirstein, supra note 15, at 207 (explaining that because the IRS' costs of litigation are fixed, they are less significant than the taxpayer's costs).

${ }^{149}$ But cf. id. 
private parties, ${ }^{150}$ and an administrative agency may tend to win a disproportionate amount of small-stakes cases while losing a disproportionate amount of large-stakes cases. ${ }^{151}$

Nonetheless, the fact that the study's results, which found applicable to Tax Court cases models developed in the context of general civil litigation bodes well for the generalizability of the nonrandomness result. Of course, the specific variables that are trial predictors in Tax Court cases are not necessarily predictors in other types of cases and the presence of the IRS on one side of the litigation may alter the results of specific variables that are predictors in other types of litigation. However, the general findings of my study that cases are nonrandomly selected for trial, and that there are certain identifiable trial "predictors," are likely generalizable to other types of civil litigation and are informative for future studies of this type.

\section{CONCLUSION}

This study of recent Tax Court cases directly supports the hypothesis that cases are not randomly selected for trial; tried cases in the sample were statistically different from settled ones. The study also demonstrates that it is possible to use actual cases to test theories about which cases settle, without having the results corrupted by the restrictive assumptions of economic models. In addition, the data demonstrate that there are identifiable trial predictors in actual cases.

The specific trial predictors in Tax Court cases are useful in understanding the theoretical models of suit and settlement. They show the importance of differences in the parties' estimations of the likely outcome at trial, the importance of information and the influence the judge can have on party estimates and strategic behavior. The results also show the importance of administrative dispute resolution in the settlement process. Although the specific results of this study are not necessarily generalizable outside of Tax Court, the insights into the applicability of the leading theories on suit and settlement should be.

${ }^{150}$ See Eisenberg, supra note 1, at 1600 (showing that the United States government fared much better at trial than other employment claim plaintiffs and modestly better at trial than other defendants). However, this result could be attributable to repeat-player effects as hypothesized by the external effects model of case selection. See supra note 35 and accompanying text.

51 Judge Posner demonstrates that where an agency brings mostly small cases, this may reflect a proper allocation of the agency's resources. See Posner, supra note 60, at 311-15. In Tax Court, the IRS recovers a much higher percentage of the amount at stake in small cases than in large cases. See Guttman, supra note 60 at 155 ("According to IRS statistics, in the first 11 months of fiscal 1993, the IRS recovered about 17 cents on the dollar in cases with over $\$ 10$ million at issue. Of the 87 cases settled without trial, it got 12 cents on the dollar. At the same time, of the 30,263 cases settled with under $\$ 10$ million at issue, the IRS got about 42 cents on the dollar."). The overwhelming majority of Tax Court cases are smaller-stakes cases. See id. at 156 ("Docketed cases with over $\$ 10$ million at issue represent a mere handful of the cases the IRS litigates. For example, in June 1993, the overall Tax Court inventory contained 41,631 cases. About 300 of these were in the over- $\$ 10$ million category. These 300 or so cases, however, represented almost $\$ 25$ billion of the nearly $\$ 38$ billion in dispute in docketed cases."). 
In addition, this study raises interesting questions for future research, such as whether variables that did not influence whether cases settle, such as the presence or absence of counsel, nonetheless influence when cases settle. ${ }^{152}$

${ }^{152}$ Because my data set contains information on the number of days that elapsed between the filing of the Tax Court petition and the entry of decision in the case, it will be possible to examine whether, for example, attorneys delay settlements. 


\section{Appendix A: Data Collection Techniques}

The data for this study were primarily collected in the summer of 1995. For opinion decisions, I used only cases closed within the prior five years, because of the Tax Court's policy of removing to a warehouse cases closed for more than five years. ${ }^{153}$ Because tens of thousands of cases are filed in Tax Court each year, ${ }^{154}$ too many for this study, I collected data on a random sample of these cases. Because only approximately five percent of Tax Court petitions result in a trial, a completely random sampling would likely have resulted in very few tried cases. In order to make meaningful comparisons between tried cases (opinion decisions) and settled cases (stipulated decisions), I over-sampled opinion decisions, selecting an approximately equal number of dockets of opinion and stipulated decisions. ${ }^{155}$ A random number generator was used to select a random subset of all opinion decisions from Lexis printouts of all Tax Court opinion decisions from 1990 to 1995 . A stratified sampling was done so that a portion was selected from each year, with the fewest selected from 1995 because it was an incomplete year at the time of the sampling. This resulted in 47 opinions decided in 1990, 46 from 1991, 51 from 1992, 45 from 1993, 44 from 1994 and 17 from 1995. Thus, I selected a total of 250 opinion decisions. ${ }^{156}$

Most of the information on opinion decisions was obtained from the opinion itself and from the CCH Tax Court Petitions Digest. The primary exception was the amount recovered by the IRS in split decisions, ${ }^{157}$ where the dollar amount was taken from the Tax Court file. In addition, information about the notice of deficiency was obtained from the file for some of these dockets.

The record in a case in which a stipulated decision was entered is destroyed one year after the decision was entered, except for the decision document stating the amount of the settlement and occasional attachments. ${ }^{158}$ Therefore, I targeted settled cases decided within the

\footnotetext{
153 There is a charge of $\$ 25$ per box to see such files. This information was obtained by telephone from Ruth Miles in the Public Files Office of the Tax Court.

${ }_{154}$ The Tax Court and the IRS both publish aggregate statistics on the amount recovered by the IRS in opinion decisions and stipulated decisions, but not on characteristics of individual cases, which is necessary for a multivariate regression analysis. Therefore, it is not possible to do a study of this type on the aggregate data.

${ }^{155}$ I accomplished this by using a random number generator to select a sample of cases from a citation list printed from a Lexis search for all Tax Court cases decided in each of the years 1990 through 1995 (the years for which the files were kept by Public Files at the time I did the study).

${ }_{156}$ A few additional opinion decisions arose out of the random docket number list discussed below.

${ }^{157}$ Under Tax Court Rule 155, the Tax Court asks the parties to submit a calculation, usually because neither party won completely on all issues. See TAX CT. R. 155.

Court.

${ }^{58}$ This information was obtained by telephone from Charles S. Casazza, Clerk of the Tax
} 
one-year period preceding data collection. ${ }^{159}$ However, I included some settled cases that were older, although it was not possible to get complete information on them from Tax Court files.

Settled cases were selected by using the CCH Tax Court Petitions Digest's list of docket numbers from 1989 through 1994. These years were selected as most likely to have resulted in a settlement within the one-year period prior to data collection. Based on information that most cases settle in the month before trial and that most trials in regular cases are scheduled approximately one year after the petition is filed, ${ }^{160} 1992$ and 1993 were targeted as the years most likely to have cases that settled in the relevant one-year period, so I over-sampled from those years, taking 100 dockets from 1989, 80 dockets from 1990, 100 dockets from 1991, 150 dockets from 1992, 133 from 1993 and 70 from 1994. The goal was 250 stipulated decisions. I selected extra dockets because there was no way of knowing in advance how many of the dockets would represent small tax cases, cases that were still pending or other dockets we would need to exclude. ${ }^{161}$ The CCH Tax Court Docket Dispositions Digest was useful in providing an indication of whether the docket had been disposed of. I used the data on all random dockets possible, even if it actually was an opinion decision. A few dockets were duplicative of decisions already identified from the opinion list and were not included twice. Where a docket number reflected a case that was still pending, I noted that information. Using this method, I was able to obtain information on 304 opinion decisions and 265 stipulated decisions. ${ }^{162}$

After collecting the data, I eliminated cases from the sample that were not deficiency cases, ${ }^{163}$ had not been resolved at the time of data collection or had been dismissed for lack of jurisdiction. ${ }^{164}$ This left a total of 479 cases, of which $48 \%$ were opinions and $52 \%$ were settled. ${ }^{165}$

${ }^{159}$ Most of the data was collected in the summer of 1995.

160 See Tannenwald, supra note 53, at 826.

161 The statistician expected the usable cases from the docket list, for each of the years $1989-1994$ to be $10,20,30,60,80$ and 50 , respectively.

${ }^{162}$ I attempted to follow up later with the Tax Court to obtain disposition information on cases that had not yet been decided at the time of data collection but was I denied access to additional Tax Court files because the Tax Court believes the files are meant for parties and their attorneys, not researchers.

${ }_{163}$ The Tax Court also has declaratory judgment jurisdiction over such matters as the taxexempt status of an entity. See I.R.C. $\$ 7428$ (1997).

I I employed the conventional alpha of .05 (the level of Type I error, i.e., false positives). See infra note 173. The power, which is one minus the Type II error (false negatives), increases with the sample size. See FINKELSTEIN \& LEVIN, supra note 52, at 186-87. I chose a sample size of approximately 400 cases, in order to reduce the level of Type II error to $20 \%$. I decided to collect information on approximately 500 cases in case I had to eliminate more cases than I originally expected.

${ }_{165}$ The initial list of cases included 569 cases. After eliminating those docket numbers that corresponded to small tax cases (which were not available to the public), non-deficiency cases and those that had not yet been decided, 479 remained. See Appendix D for statistics on the 479 cases. 
In the set of 479 cases that remained after unusable cases were eliminated, there were 84 decisions from 1990, 41 of which were opinions; 70 from 1991, 41 of which were opinions; 86 from 1992, 48 of which were opinions; 101 from 1993, 39 of which were opinions; 107 from 1994, 41 of which were opinions; and 31 from 1995, 20 of which were opinions. 
In order to isolate the effect of each of the nine "independent variables" (STAKES, APPEALS, JUDGETYPE, DECADE, BACKGROUND, PARTY, TAXPAYER, REGION and COUNSEL), on the dependent variable, settlement or trial outcome (TRIAL), I used a multivariate logit (or "logistic") ${ }^{166}$ regression analysis. ${ }^{167}$ Multivariate regression permits examination of the separate effect ${ }^{168}$ of each of the independent variables on the dependent variable, while controlling for all of the other independent variables. ${ }^{169}$ This enabled me to both test the hypothesis that tried cases differ from settled ones, in observable ways, and to isolate some of the characteristics that are the predictors of cases that will go to trial. ${ }^{170}$

Multiple regression requires eliminating any case that does not contain information on all of the independent variables used in a particular run. ${ }^{171}$ As a result, because of gaps in information on some of

${ }^{166}$ Logistic regression was used because where the dependent variable has a dichotomous outcome (here, trial or settlement), ordinary least squares regression can not be used because the assumption that the errors are homoskedastic is violated. See FINKELSTEIN \& LEVIN, supra note 51, at 448; Deborah Jones Merritt \& Barbara F. Reskin, Sex, Race, and Credentials: The Truth About Affirmative Action in Law Faculty Hiring, 97 COLUM. L. REV. 199, 238 n.123 (1997).

${ }_{16}$ Most of the statistical analyses were done with the LR program of BMDP software. A few runs were done using SPSS. For coding purposes, the dependent variable (TRIAL) was coded with opinion as "success" and settlement as "failure." See Appendix C for the equation used.

${ }^{168}$ See Merritt \& Reskin, supra note 166 , at 239 n.125. ("Regression analyses detect only relationships between independent and dependent variables; they cannot prove causal connections between those variables. However, when an independent variable precedes a dependent variable in time, when independent variables are chosen for their theoretical link to the dependent variable, and when the analysis controls for possibly confounding factors, it is reasonable to infer that independent variables with significant partial coefficients causally influenced the dependent variable.").

${ }^{169}$ See, e.g., Hall et al., supra note 49, at 1066 ("Multiple regression is a statistical technique that determines the effect of a single factor on a designated outcome, holding all other factors constant. Therefore, it is capable of separating out the commingled effects of many factors."); Deborah J. Merritt et al., Family, Place, and Career: The Gender Paradox in Law School Hiring, 1993 WIS. L. REV. 395, 422 ("Multiple regression is an analytic technique that estimates the independent (or 'partial') effect of each of several independent variables ... on a dependent variable....").

${ }^{170}$ It is of course possible that there are other predictors of cases that will be selected for trial. However, that possibility does not undermine the statistical significance of the data used in this study. Instead, all multiple regression equations use an "error term," which is a constant, to account for the possibility that other independent variables are predictors of the dependent variable.

${ }^{171}$ The data can be envisioned as a matrix with case numbers listed down the left side and independent variables listed across the top. If a particular case does not have information on a particular variable, there is an empty cell. Because the computer requires all cells to have data, either an empty cell must be filled with an approximation (based on the predictions from the other data), the case must be removed, or the variable must be removed from the analysis. Filling in the cell merely serves to artificially increase statistical significance by artificially increasing sample size; the prediction for the value in the missing cell is based on the predictions of the other cases for which there is data. Thus, it is better to eliminate the case from the run or to eliminate that variable in some runs.

Because approximately $25 \%$ of the cases were missing information on the APPEALS variable, and because of its importance in the analyses, I did several runs on both the main group of cases and the subset of 342 cases containing information on the APPEALS variable, in 
my cases, particularly settled cases, I was not able to do regressions on the full set of cases; I used a subset of 342 cases for some of the analyses. ${ }^{172}$ The results of the regressions on the subset of 342 cases were very consistent with the regressions on larger groups of cases, reinforcing those results obtained from the smaller runs.

A multiple regression run indicates the "statistical significance" of each independent variable in predicting the dependent variable. ${ }^{173}$ Each of these variables was a categorical variable with one reference group and one or more additional groups. ${ }^{174}$ For example, the STAKES variable was divided into four groups, so that each case was put into one of the four groups, depending on the dollar amount at stake in the case. Logistic regression provides the "log odds" for each variable. Log odds is the number of times by which an outcome (here, opinion decision) is more likely in a particular group, compared

order to see if the data sets were different in some other way that would skew the results obtained in runs with the smaller group of cases. My results were generally consistent, see Appendix $E$, although, as discussed below, there were differences between the 342 cases and the 137 cases that were not included in the runs of the 342 cases. Settled cases were disproportionately missing the APPEALS variable. See Appendix E. Unfortunately, the Tax Court's policy of destroying most of the file in settled cases one year after entry of decision limited my ability to fill in missing APPEALS information in those cases.

${ }_{172}$ The 342 cases were not completely representative of the 479 cases. Individual comparisons by variable of what percent of the cases in each group, (the 342 cases and the 137 cases that were excluded from the smaller runs), fell into the categories for that variable, revealed compositional differences in each variable. This is not surprising because the smaller set was not randomly selected but rather reflected those cases that had complete information. Most of the missing information was missing disproportionately from settled cases, as explained above. See supra note 171 . Of the 342 cases, $58.5 \%$ were opinion decisions and $41.5 \%$ were settled. That should be contrasted with the cases that were removed (the 137 cases), of which only $21.9 \%$ were opinion decisions. Decisions that were removed were most often missing APPEALS information, but were sometimes missing STAKES data. Less often, the case was missing data on another variable, such as REGION, which, for settled decisions, was only available from the taxpayer's petition, and thus not available after the file was destroyed. I was able to fill in some gaps in information in cases where the taxpayer had counsel from the CCH Tax Court Petitions Digest. The CCH Tax Court Petitions Digest does not have specific information for cases in which the taxpayer was pro se.

Because the group of 342 cases is not representative of the full set of cases, results from runs on that subset must be viewed with caution. However, because they were generally consistent with runs on larger sets of cases, see Appendix $E$, they were helpful in seeing the effect of the APPEALS variable, which could only be included as a variable in the larger runs. At the optimum cut point, runs on the 342 cases predicted $70 \%$ to $75 \%$ of the cases correctly, with results skewed toward correctly predicting opinion decisions.

${ }_{173}$ See Gross \& Syverud, Getting to No, supra note 12, at 334 n.48. ("Statistical significance-commonly denoted by 'p-values'-is a measure of the probability that a deviation from an expected pattern of events as extreme as that observed, or more extreme, would have $o c-$ curred if the process that produced the observed pattern were mere chance. Thus a p-value of .01 (or a statement that a difference is 'significant at the .01 level') signifies that the observed deviation from the expected pattern, or a more extreme one, would have occurred by chance no more often than one time in one hundred. By a venerable but arbitrary scientific convention, findings are said to be 'statistically significant' if they could have occurred by chance one time in twenty or less often-that is, if they have a p-value of .05 or smaller. Note that the smaller the p-value the greater the confidence that the results do not reflect mere chance fluctuations.")

The $p$-values reported in Appendices $E$ and $F$ reflect the statistical significance of each independent variable as a whole. That is, for a variable such as STAKES, the $p$-value reflects the joint values of the $F$ test for each of the STAKES dummy variables.

174 See Appendix D for a list and explanation of the variables. A "categorical" variable is one that is divided into categories (such as represented or pro se) rather than "continuous" which reflects a range of values (such as dollars). See Appendix D for information about how many cases had values in each group of each independent variable. 
to the reference group, controlling for the effect of the other independent variables. ${ }^{175}$ The confidence interval for the log odds ratio gives a range within which there is $95 \%$ confidence level that the true log odds fall. ${ }^{176}$

One objective in a regression analysis is to select the fewest independent variables that are the most predictive of the dependent variable, here TRIAL (trial or settlement outcome). ${ }^{177}$ "Stepwise" regressions were used as a tool to select the strongest subset of the nine variables. In a stepwise regression, at each step in the process, the computer program ranks the variables in order of significance, removes the least significant variable, and runs the analysis again, with the objective of retaining only the statistically significant independent variables in the regression equation. ${ }^{178}$ For my strongest model, ${ }^{179}$ I chose the variables to include based not only on the stepwise regressions but also on other runs on various groups of variables.

${ }^{175}$ For example, for STAKES, the regression provides a log odds ratio that provides how many times more likely a case is to go to trial in the particular group (such as cases with stakes of more than $\$ 500,000$ ) compared to the reference group of zero to $\$ 10,000$.

APPEALS was grouped into cases that went to the Appeals Office prior to docketing and those that did not, with those that did as the reference group. The STAKES variable was grouped into four categories, zero to $\$ 10,000 ; \$ 10,001$ to $\$ 100,000 ; \$ 100,001$ to $\$ 500,000$; and over $\$ 500,000$; with zero to $\$ 10,000$ as the reference group. For JUDGETYPE, judge (as opposed to Special Trial Judge) was the reference group. DECADE was grouped into judicial appointments in the 1960s to 1970 s (the reference group), 1980s, and 1990s. BACKGROUND had three categories, the reference group of "private," where the judge or Special Trial Judge's background was in the private sector, government or both. For PARTY, Republican was the reference group. For COUNSEL, pro se was the reference group. REGION, the area of the country in which the taxpayer resided at the time he petitioned the Tax Court, was grouped into the seven IRS regions that existed prior to 1996, with the Central region as the reference group. TAXPAYER used individuals as the reference group, corporations as another group and "other" as the final group. See Appendix E.

${ }^{176}$ In other words, if the $\log$ odds for a particular group is 2.30 , then cases with that feature are 2.30 times more likely to go to trial and opinion than cases in the reference group (cases without that feature). If the confidence interval is 1.83 to 4.22 , then the "true" log odds has a $95 \%$ likelihood of falling between those two numbers. If the confidence interval includes 1 , then it is possible that the particular group is equally likely as the reference group to go to trial and opinion, which means that the relationship observed for that particular group could have occurred by chance.

7 See FINKELSTEIN \& LEVIN, supra note 52, at 356-57 ("In general, then, the objective in a regression model is to achieve 'parsimony' by including the fewest factors that explain the most variation in the dependent variable with the greatest degree of statistical significance for each factor.").

${ }_{178}$ See id. (explaining process of stepwise regression).

${ }^{179}$ See Appendix E, Model 5. 
Appendix C: Equation and Variables

To determine if particular case features predict an increase likelihood of trial, the estimated equation ${ }^{180}$ is:

$\log ($ TRIAL/1-TRIAL $)=$ constant $+\mathrm{a}^{*}$ APPEALS + $b *$ STAKES + $c$ *JUDGETYPE + d*DECADE +

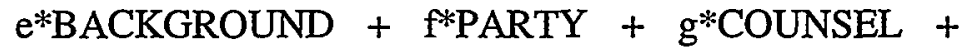
$\mathrm{h} *$ REGION + $\mathrm{i}$ *TAXPAYER

The variables used in the equation are as follows:

\section{Dependent Variable}

TRIAL is a dummy variable equal to 1 for a tried case (opinion decision) and 0 for a settled case (stipulated decision).

\section{Independent Variables}

APPEALS is a dummy variable reflecting whether the case went though the IRS appeals process prior to Tax Court docketing. The reference group is cases that went through the pre-docketing process. STAKES is the size of the dollar amount at stake in the case. It is categorical, with cutpoints at $\$ 10,000 ; \$ 100,000 ; \$ 500,000$; and $\$ 1,000,000$. $\$ 0$ to $\$ 10,000$ is the reference group.

JUDGETYPE is a dummy variable for the kind of judge assigned to the case, regular judge or Special Trial Judge. The reference group is regular judge.

DECADE is a categorical variable for the decade in which the judge in the case was appointed to the bench. The reference group is 1960 s to 1970 s. The other two groups are 1980s and 1990s.

BACKGROUND is a categorical variable for the judge's background prior to appointment to the bench. Private sector is the reference group, and the other two groups are (1) government and (2) both private sector and government experience.

PARTY is a dummy variable for the political party of the President that appointed the judge, or in the case of Special Trial Judges, the President who appointed the Chief Judge who appointed the Spe-

${ }^{180}$ The equation differs depending on the model in that, as shown in Appendix E, not all independent variables are included in all runs, so the equation must be modified to drop any variable not included in that run. 
cial Trial Judge. Republican is the reference group, and Democrat is the other group.

COUNSEL is a dummy variable for whether or not the taxpayer was represented in the Tax Court. Pro se is the reference group.

REGION is a categorical variable for the region in which the taxpayer resided at the time he invoked the Tax Court=s jurisdiction. There are seven groups in REGION, corresponding to the seven IRS regions that existed at the time the cases in the sample were decided by the Tax Court. Central is the reference group. The other regions are Midatlantic, Midwest, Northatlantic, Southeast, Southwest, and West.

TAXPAYER is a categorical variable for the type of taxpayer in the case. Corporation is the reference group. The other two groups are (1) individual and (2) other. 
Appendix D: The Variables-Descriptive Statistics

$$
n=479^{181}
$$

TRIAL $^{182}$ (n=479): 230 (48.02\%) opinion, 249 (51.98\%) settled

APPEALS ( $\mathrm{n}=355): 31.38 \%$ appeals; $68.62 \%$ not appeals. Of opinion cases, $43.56 \%$ are appeals and $56.44 \%$ are not appeals; of settled cases, $16.34 \%$ are appeals and $83.66 \%$ are not appeals.

STAKES $(\mathrm{n}=391): 22.25 \%$ are $\$ 0-\$ 10,000 ; 45.78 \%$ are $\$ 10,000$ $\$ 100,000 ; 17.39 \%$ are $\$ 100,000-\$ 500,000 ; 4.86 \%$ are $\$ 500,00-\$ 1$ million; and $9.72 \%$ are over $\$ 1$ million. Of opinion cases, $20.35 \%$ are $\$ 0-\$ 10,000 ; 39.82 \%$ are $\$ 10,000-\$ 100,000 ; 19.91 \%$ are $\$ 100,000$ $\$ 500,000 ; 7.08 \%$ are $\$ 500,000-\$ 1$ million; and $12.83 \%$ are over $\$ 1$ million. Of settled cases, $24.85 \%$ are $\$ 0-\$ 10,000 ; 53.94 \%$ are $\$ 10,000-\$ 100,000 ; 13.94 \%$ are $\$ 100,000-\$ 500,000 ; 1.82 \%$ are $\$ 500,000-\$ 1$ million; and $5.45 \%$ are over $\$ 1$ million.

JUDGETYPE ( $\mathrm{n}=479): 78.71 \%$ judges; $21.29 \%$ Special Trial Judges. Of opinion cases, $75.65 \%$ are judges and $24.35 \%$ are Special Trial Judges. Of settled cases, $81.53 \%$ are judges and $18.47 \%$ are Special Trial Judges.

DECADE ( $\mathrm{n}=479$ ): $29.65 \%$ 1960s-1970s; 61.17\% 1980s; 9.19\% 1990s. Of opinion cases, $29.13 \%$ are $1960 \mathrm{~s}-1970$ s; $58.26 \%$ are $1980 \mathrm{~s} ; 12.61 \%$ are $1990 \mathrm{~s}$. Of settled cases, $30.12 \%$ are $1960 \mathrm{~s}-1970 \mathrm{~s}$; $61.17 \%$ are $1980 \mathrm{~s} ; 9.19 \%$ are 1990 s.

BACKGROUND ( $\mathrm{n}=479): 14.61 \%$ have private sector experience; $25.68 \%$ have a government background; $59.71 \%$ have both. Of opinion decisions, $16.52 \%$ have private sector experience, $37.39 \%$ have a government background; $46.09 \%$ both. Of settled decisions, $12.85 \%$ have private sector experience, $14.86 \%$ have a government background; $72.29 \%$ have both.

${ }^{181}$ The full set of cases is 479 cases. However, because there is not complete information on each independent variable, I have noted the sample $(n)$ size next to each variable.

${ }^{182}$ TRIAL is the dependent variable. 
PARTY ( $\mathrm{n}=479$ ): $62.42 \%$ Republican; $37.58 \%$ Democrat. Of opinion cases, $61.74 \%$ Republican; $38.26 \%$ Democrat. Of settled cases, 63.05\% Republican; 36.95\% Democrat.

COUNSEL ( $\mathrm{n}=428): 32.24 \%$ are pro se; $67.76 \%$ are represented. Of opinion decisions, $32.17 \%$ are pro se; $67.83 \%$ are represented. Of settled decisions, $32.32 \%$ are pro se; $67.78 \%$ are represented.

REGION ( $\mathrm{n}=413$ ): $10.65 \%$ Central; $7.02 \%$ Midatlantic; $9.44 \%$ Midwest; $9.93 \%$ Northatlantic; $14.04 \%$ Southeast; $19.85 \%$ Southwest; $29.06 \%$ West. Of opinion decisions, $13.06 \%$ Central; $8.56 \%$ Midatlantic; $9.01 \%$ Midwest; $8.56 \%$ Northatlantic; $13.96 \%$ Southeast; 20.27\% Southwest; $26.58 \%$ West. Of settled decisions, $7.85 \%$ Central; 5.24\% Midatlantic; $9.95 \%$ Midwest; $11.52 \%$ Northatlantic; 14.14\% Southeast; $19.37 \%$ Southwest; $31.94 \%$ West.

TAXPAYER ( $\mathrm{n}=475): 10.74 \%$ corporations; $84.0 \%$ individuals; $5.26 \%$ other. Of opinion cases, $12.72 \%$ are corporations; $82.02 \%$ are individuals; $5.26 \%$ are other. Of settled cases, $8.91 \%$ are corporations; $85.83 \%$ are individuals; $5.26 \%$ are other. 
Appendix D (continued): The Variables

$$
n=342^{183}
$$

TRIAL: 200 (58.5\%) opinion, 142 (41.5\%) settled

APPEALS: $32.2 \%$ appeals; $67.8 \%$ not appeals. Of opinion cases, $43.5 \%$ are appeals and $56.5 \%$ are not appeals; of settled cases, $16.2 \%$ are appeals and $83.8 \%$ are not appeals.

STAKES: $22.5 \%$ are $\$ 0-\$ 10,000 ; 43.9 \%$ are $\$ 10,000-\$ 100,000$; $18.1 \%$ are $\$ 100,000-\$ 500,000$; and $15.5 \%$ are over $\$ 500,000$. Of opinion cases, $21.5 \%$ are $\$ 0-\$ 10,000 ; 36.5 \%$ are $\$ 10,000-\$ 100,000$; $20.5 \%$ are $\$ 100,000-\$ 500,000$; and $21.5 \%$ are over $\$ 500,000$. Of settled cases, $23.9 \%$ are $\$ 0-\$ 10,000 ; 54.2 \%$ are $\$ 10,000-\$ 100,000$; $14.8 \%$ are $\$ 100,000-\$ 500,000$; and $7.0 \%$ are over $\$ 500,000$.

JUDGETYPE: $81.3 \%$ judges; $18.7 \%$ Special Trial Judges. Of opinion cases, $76.5 \%$ are judges and $23.5 \%$ are Special Trial Judges. Of settled cases, $88.0 \%$ are judges and $12.0 \%$ are Special Trial Judges.

DECADE: $23.4 \%$ 1960s-1970s; 66.7\% 1980s; 9.9\% 1990s. Of opinion cases, $30.5 \%$ are $1960 \mathrm{~s}-1970 \mathrm{~s} ; 58.5 \%$ are $1980 \mathrm{~s} ; 11.0 \%$ are 1990s. Of settled cases, $13.4 \%$ are $1960 \mathrm{~s}-1970 \mathrm{~s} ; 78.2 \%$ are $1980 \mathrm{~s}$; $8.5 \%$ are $1990 \mathrm{~s}$.

BACKGROUND: $16.1 \%$ private; $28.4 \%$ government; $55.6 \%$ both. Of opinion decisions, $17.0 \%$ have private sector experience, $35.5 \%$ have a government background; $47.5 \%$ have both. Of settled decisions, $14.8 \%$ have private sector experience, $18.3 \%$ have a government background; $66.9 \%$ have both.

PARTY: $70.5 \%$ Republican; $29.5 \%$ Democrat. Of opinion cases, $61.5 \%$ Republican; 38.5\% Democrat. Of settled cases, $83.1 \%$ Republican; $16.9 \%$ Democrat.

\footnotetext{
${ }^{183}$ This set of 342 cases is a subset that was used for many runs because it enabled inclusion of the key independent variables. REGION and TAXPAYER were not included in runs on the set of 342 cases because they were not statistically significant in any run.
} 
COUNSEL: $33.9 \%$ pro se; $66.1 \%$ represented. Of opinion decisions, $27.0 \%$ pro se; $73.0 \%$ represented. Of settled decisions, $43.7 \%$ pro se; $56.3 \%$ represented. 


\section{Appendix E:}

Logistic Regression Results for TRIAL: p-valuesfor each Variable and Exp(Coef) with Parenthetical 95\% Confidence Interval for each Group with Respect to the Reference Group for that Variable ${ }^{184}$

\begin{tabular}{|c|c|c|c|c|c|}
\hline & $\begin{array}{l}\text { Model] } \\
\mathrm{n}=37^{185}\end{array}$ & $\begin{array}{l}\text { Model } 2 \\
n=387\end{array}$ & $\begin{array}{l}\text { Model } 3 \\
n=387\end{array}$ & $\begin{array}{l}\text { Model4 } \\
n=342\end{array}$ & $\begin{array}{l}\text { Model.5 } \\
n=346\end{array}$ \\
\hline \multicolumn{6}{|l|}{ VARIABLE: reference group } \\
\hline APPEALS: Pre-docketing IRS appeal & & & & $p=.0000$ & $p=.0000$ \\
\hline No pre-docketing IRS appeal & & & & $.260(.146, .463)$ & $.241(.137,4.26)$ \\
\hline STAKES: $50-\$ 10,000$ & $p=.0003$ & $p=.0009$ & $p=0009$ & $p=.0057$ & $p=.0003$ \\
\hline S10,001-S100,000 & $1.82(.914,3.62)$ & $1.61(.828,3.14)$ & $1.71(.871,3.37)$ & $1.67(.763,3.66)$ & $1.67(.780,3.59)$ \\
\hline$\$ 100,001-\$ 500,000$ & $4.51(1.85,11.0)$ & $3.00(1.33,6.81)$ & $3.22(1.40 .7 .37)$ & $2.50(.980,6.35)$ & $2.81(1.14,6.92)$ \\
\hline SOver $\$ 500,000$ & $9.28(3.33,25.9)$ & $5.95(2.38,14.9)$ & $6.30(2.49,15.9)$ & $6.29(2.19,18.0)$ & $7.12(2.59,19.6)$ \\
\hline JUDGETYPE: Regular judge & $p=.0321$ & $p=.0003$ & $p=.0263$ & $p=.0719$ & $p=.0016$ \\
\hline Special Trial Judge & $2 \pi 7(1.15,6.65)$ & $3.99(1.94,8.21)$ & $2.67(1.16,6.17)$ & $247(.942,6.49)$ & $3.81(1.68,8.60)$ \\
\hline DECADE: 1960 s. $1970 \mathrm{~s}$ & $p=.4313$ & $p=.0586$ & & $p=.1638$ & $p=.0077$ \\
\hline $1980 \mathrm{~s}$ & $.775(.372,1.61)$ & $.532(.300, .943)$ & & $519.232,1.16)$ & $.364(.189 . .700)$ \\
\hline $1990 \mathrm{~s}$ & $1.28(.445,3.60)$ & $.906(360,2.28)$ & & $.884(.278,281)$ & $.629(.220,1.80)$ \\
\hline BACKGROUND: Privase sector & $p=0078$ & $p=.0027$ & $p=.0016$ & $P=.0390$ & $p=.0431$ \\
\hline Government & $1.72(.738,3.99)$ & $1.77(.794,3.94)$ & $1.84(.826,4.11)$ & $1.17(.474,288)$ & $1.21(.493,2.95)$ \\
\hline Both & $.643(.311,1.33)$ & $.663(.337,1.31)$ & $.638(324,1.26)$ & $.556(.259,1.19)$ & $.583(.273,1.24)$ \\
\hline PARTY: Republican & $p=.1199$ & & $p=.0993$ & $p=.1349$ & \\
\hline Democrat & $1.93(.885,4.21)$ & & $1.94(.910,4.14)$ & $1.93(.829,4.51)$ & \\
\hline COUNSEL: Pro se & $P=.4946$ & $p=6299$ & $p=.7385$ & $p=.4088$ & \\
\hline Represented & $1.21(.720,204)$ & $1.13(.697,1.84)$ & $1.09(.667,1.78)$ & $1.27(.728,2.22)$ & \\
\hline REGION: Central & $p=6463$ & & & & \\
\hline Midallantic & $.841(.272,260)$ & & & & \\
\hline Midwest & $.437(.157,1.22)$ & & & & \\
\hline Northarkantic & $.409(.149,1.13$ & & & & \\
\hline Southeast & $.492(.193,1.26)$ & & & & \\
\hline Southwest & $.648(.275,1.53)$ & & & & \\
\hline West & $.597(.261,1.37)$ & & & & \\
\hline TAXPAYER: Comoration & $p=.0932$ & & & & \\
\hline Individual & $1.41(.643,3.10)$ & & & & \\
\hline Other & $.405(.126,1.30)$ & & & & \\
\hline
\end{tabular}
variable.

${ }^{184}$ The reference group for each variable appears in italics next to the name of the ${ }^{185} n$ is the number of cases included in the particular run. The number varies because the computer can not include any case missing a value for any variable included in that run. 


\section{Appendix F:}

Logistic Regression Results for TRIAL:

Comparison of Runs on STAKES, JUDGETYPE, DECADE, BACKGROUND, PARTY and COUNSEL, with and without Interaction Term for DECADE and PARTY

$p$-value for each variable, $\operatorname{Exp}(\mathrm{Coef})$ for each group, and, in parenthesis, 95\% confidence interval for each $\operatorname{Exp}(\mathrm{Coef})$

$\underset{n=387}{\text { Without Interaction Term }} \quad \underset{n=387}{\text { With Interaction Term }}$

VARIABLE: reference group

STAKES: $\$ 0-\$ 10,000^{186}$

$\$ 10,001-\$ 100,000$

$\$ 100,001-\$ 500,000$

Over $\$ 500,000$

JUDGETYPE: Regular judge

Special Trial Judge

DECADE: $1960 s-1970 s$

1980s

$1990 \mathrm{~s}$

BACKGROUND: Private sector

Government

Both

PARTY: Republican

Democrat

COUNSEL: Pro se

Represented

$\begin{array}{ll}p=.0009 & p=.0008 \\ 1.71(.871,3.37) & 1.70(.861,3.36) \\ 3.22(1.40,7.37) & 3.23(1.40,7.42) \\ 6.30(2.49,15.9) & 6.38(2.51,16.2)\end{array}$

$p=.0268$

$p=.1578$

2.67(1.16, 6.17)

$2.05(.783,5.39)$

$p=.3324$

$-^{187}$

$.789(.387,1.61)$

$.550(.199,1.52)$

$1.39(.497,3.88)$

$1.07(.309,3.68)$

$p=.0036$

$1.78(.793,3.98)$

$.652(.330,1.29)$

$.638(.324,1.26)$

$p=.0993$

$-^{188}$

$1.94(.910,4.14) \quad 1.31(.436,3.92)$

$p=.7385$

$p=.7716$

$1.09(.667,1.78)$
$1.08(.658,1.77)$ variable.

${ }^{186}$ The reference group for each variable appears in italics next to the name of the ${ }^{187}$ The $p$ value is absent here because I used DECADE * PARTY in this run.

${ }^{188}$ See supra note 187. 